\title{
A Novel Multilevel Inverter Circuit for the Performance Enhancement of Direct Torque Controlled Induction Motor
}

\author{
Manoj Kumar Nadesan, Geetha Ramadas*, Chellamuthu Chinnagounder \\ Department of Electrical and Electronics Engineering, R.M.K Engineering College, Chennai, India \\ Email:nmanojkumar_17@yahoo.co.in, "gita_ramadas@yahoo.com \\ Received 14 April 2016; accepted 10 May 2016; published 29 July 2016 \\ Copyright @ 2016 by authors and Scientific Research Publishing Inc. \\ This work is licensed under the Creative Commons Attribution International License (CC BY). \\ http://creativecommons.org/licenses/by/4.0/ \\ (c) (i) Open Access
}

\begin{abstract}
Induction motor is the most sought after motor in the industry for excellent performance characteristics and robustness. Developments in the Power Electronic circuitry have revolutionised the induction motor industry leading to the developments in various control strategies and circuits for motor control. Direct Torque Control (DTC) is one of the excellent control strategies preferred by industries for controlling the torque and flux in an induction machine. The main drawback of DTC is the presence of torque ripple which is slightly more than the acceptable limit. There are various parameters that introduce ripples in the electromagnetic torque, one of them being the type of inverter circuit. There are various types of inverter circuits available and the effect of each of them in the production of torque ripple is different. This work is an attempt to identify the influence of various multilevel inverter circuits on the torque ripple level and to propose the best inverter circuit. The influence of multilevel diode clamped inverter and cascaded $H$ bridge inverter circuits on torque ripple minimization, is analysed using simulation studies for identifying the most suitable multilevel inverter circuit which gives minimum torque ripple. The results obtained from the simulation studies are validated by hardware implementation on $0.75 \mathrm{~kW}$ induction motor.
\end{abstract}

\section{Keywords}

Diode Clamped Inverter Circuit, Cascaded H Bridge Inverter, Direct Torque Control, Proportional Integral Controller, Space Vector Modulation, Induction Motor

\section{Introduction}

Direct torque control is one of the most widely adapted schemes of control of induction motors. It is one of the

\footnotetext{
${ }^{*}$ Corresponding author.
}

How to cite this paper: Nadesan, M.K., Ramadas, G. and Chinnagounder, C. (2016) A Novel Multilevel Inverter Circuit for the Performance Enhancement of Direct Torque Controlled Induction Motor. Circuits and Systems, 7, 2771-2794. 
simplest methods to control the stator flux and electromagnetic torque simultaneously. A detailed study on DTC, dealing with the historical and recent developments and major milestones [1] in control of induction motors, is carried out and the results are translated into the latest industrial standards along with the current trends in research and industry for easy reference to all researchers. To reduce the torque ripple and to improve dynamic and steady state responses, an adaptive step flux algorithm is proposed [2] [3]. A space vector modulation technique with two level inverter circuits replacing the hysteresis comparators is proposed to improve the flux and torque ripples [4]. Lakshmi Swarupa et al. [5] presented a three level Space Vector Modulation (SVM) for two parallel connected two-level inverters having DC supply connected through a dc-link. A new algorithm [6] is proposed for direct speed and flux adaptive controls of induction motor using unknown time-varying rotor resistance and load torque. A new control strategy [7] [8] for the three level inverter fed induction motors based on DTC is replaced by a two level inverter to improve the transient and steady state response. The DTC-SVM control for asynchronous machines [9] is introduced to synthesize the voltage space vector accurately to reduce the torque and flux ripples and to enhance the steady state performance. A pre excitation method [10] is discussed for improving the starting current of induction motor. A novel switching technique [11] with large number of voltage sectors is proposed to reduce the torque ripple. Chandra Sekhar et al. [12] presented a study of DTC technique for voltage source inverter fed induction motor using MATLAB/Simulink model based on the hysteresis controllers for flux and torque ripple control. An improved FPGA method [13] has been proposed for the implementation of DTC of IM. The hybrid closed loop [14] DTC method was used for the performance improvement. A fuzzy logic hysteresis comparator based DTC scheme [15] [16] for an induction motor is proposed under varying dynamic conditions An online self tuned neuro fuzzy hysteresis controller [17] is proposed to reduce the steady state torque ripple.

The main application of direct torque control of induction motor drive is to control the flux linkage and electromagnetic torque directly by selecting proper inverter switching state with the help of a predefined lookup table. Conventional DTC uses two level and three level hysteresis controllers for flux and torque controls respectively. Even though it has many advantages like no feedback control, no traditional PWM algorithm, no vector transformation, it has some drawbacks like variable switching frequency, inherent steady state torque and flux ripples. Due to hysteresis band controller, steady state torque and flux ripples are high in the direct torque control of induction motor which is undesirable.

This paper deals with a novel inverter circuit along with the appropriate controller for reducing the torque ripple in a DTC scheme as applied to an Induction motor. Study is initially carried out in open loop mode using hysteresis comparator. The main draw back with hysteresis comparator is the introduction of torque ripple. Then, the study is repeated in closed loop mode with PI controller replacing the hysteresis comparator. Space vector modulation technique is adapted along with PWM technique for a three level inverter. The work carried out is presented as given below.

Section 2 deals with the mathematical modelling of induction motor. Section 3 deals with the effect of various multilevel circuits in reducing the torque ripple. Three level neutral point clamped SVM circuit based DTC and the design of PI controllers are described in Section 4. Section 5 discusses about the simulation results of the proposed scheme and the proposed fuzzy based SVM-DTC is discussed in Section 6. Section 7 deals with the hardware implementation and the conclusions are discussed in Section 8.

\section{Induction Motor Modelling}

The circuit model of the induction machine with d-axis fixed along the stator flux axis is shown in Figure 1 for $d$ and $q$-axis and the equations are given from (1) to (9).

$$
\begin{gathered}
V_{d s}=R_{s} I_{d s}+P \psi_{d s} \\
V_{q s}=R_{s} I_{q s}+\omega \psi_{q s} \\
0=R_{r} I_{d r}+P \psi_{d r}-\psi_{q r}\left(\omega_{s}-p \omega_{m}\right) \\
0=R_{r} I_{q r}+P \psi_{q r}+\psi_{d r}\left(\omega_{s}-p \omega_{m}\right)
\end{gathered}
$$

where $\omega_{d A}=\left(\omega_{s}-p \omega_{m}\right)$

$$
\psi_{d s}=L_{s} I_{d s}+L_{m} I_{d r}
$$




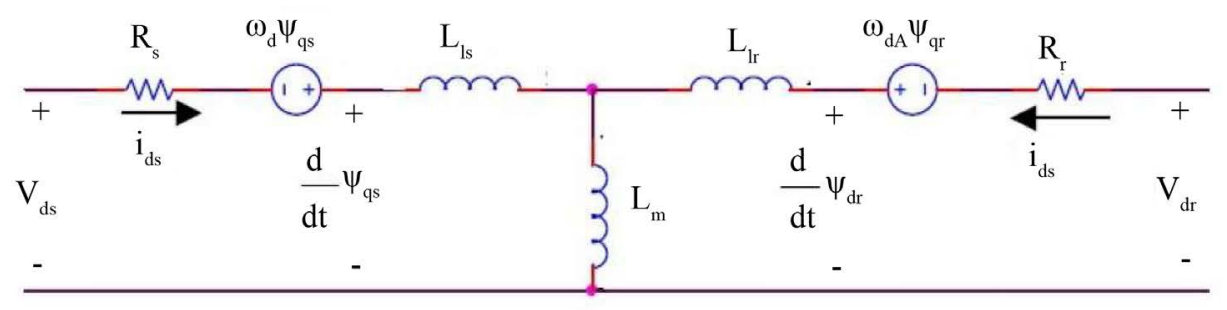

(a) d-axis

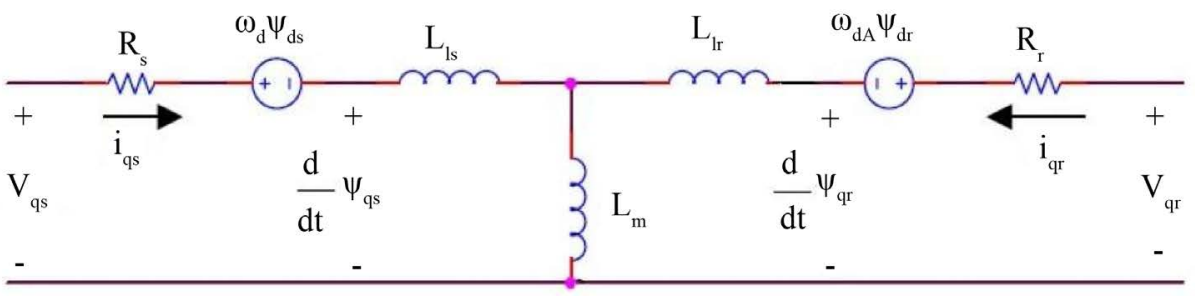

(b) q-axis

Figure 1. Equivalent circuit of motor in $d$ and $q$ axis.

$$
\begin{gathered}
\psi_{q s}=L_{s} I_{q s}+L_{m} I_{q r}=0 \\
\psi_{d r}=L_{r} I_{d r}+L_{m} I_{d s} \\
\psi_{q r}=L_{r} I_{q r}+L_{m} I_{q s} \\
T_{e}=p \frac{3}{2}\left(\psi_{d s} I_{q s}-\psi_{q s} I_{d s}\right)
\end{gathered}
$$

Since d-axis is fixed along the stator flux $\psi_{s}$, the flux $\psi_{q s}$ becomes zero. Torque can be written as

$$
T_{e}=p \frac{3}{2} \psi_{d s} I_{q s}
$$

where, $V_{d s}, V_{q s}$ are stator voltages in $d$ and $q$ axes of rotating reference frame, $I_{d s}$ and $I_{q s}$ are stator currents in $d$ and $q$ axis respectively. $\psi_{d s}$ and $\psi_{q s}$ are the direct and quadrature component of stator flux. $\psi_{d r}$ and $\psi_{q r}$ are direct and quadrature axis components of rotor flux. $R_{s}, R_{r}$ are the stator and rotor winding resistances. $L_{l s}, L_{l r}$ and $L_{m}$ are stator, rotor self and mutual inductances. $\Psi_{s}$ is the stator flux. $\omega_{m}$ is the angular motor speed. $\omega_{s}$ is the stator flux speed. $P$ denotes $\frac{\mathrm{d}}{\mathrm{d} t}, p$ represents the pole pairs.

\section{DTC with Different Multi Level Inverter Circuits}

The elementary concept of a multilevel inverter to achieve high power by a series of power semiconductor switches with several low voltage dc sources is applied for power conversion to generate staircase voltage waveforms. Capacitors, batteries, and renewable energy voltage sources can be used as the multiple dc voltage sources. Different multilevel circuits used in the proposed study are Cascaded $\mathrm{H}$ bridge multilevel inverter (CHBMLI) and Diode Clamped Multilevel Inverter (DCMLI) which are much superior to Flying Capacitor Multilevel Inverter. An induction motor drive with five level CHBMLI and seven level CHBMLI are considered for simulation study using PSIM. The simulation circuit of DTC with a five level CHBMLI in open loop mode is shown in Figure 2.

During simulation, the motor is run on no load and then load is increased gradually up to the rated load of $19 \mathrm{Nm}$. The same procedure is repeated with a seven level CHBMLI. The study is limited to inverter level up to seven as the cost and complexity may increase with levels higher than seven. The variation of the total harmonic distortion for different load torques is shown in Figure 3. It is observed that SLCHBI gives a low THD value when compared with FLCHBI. 


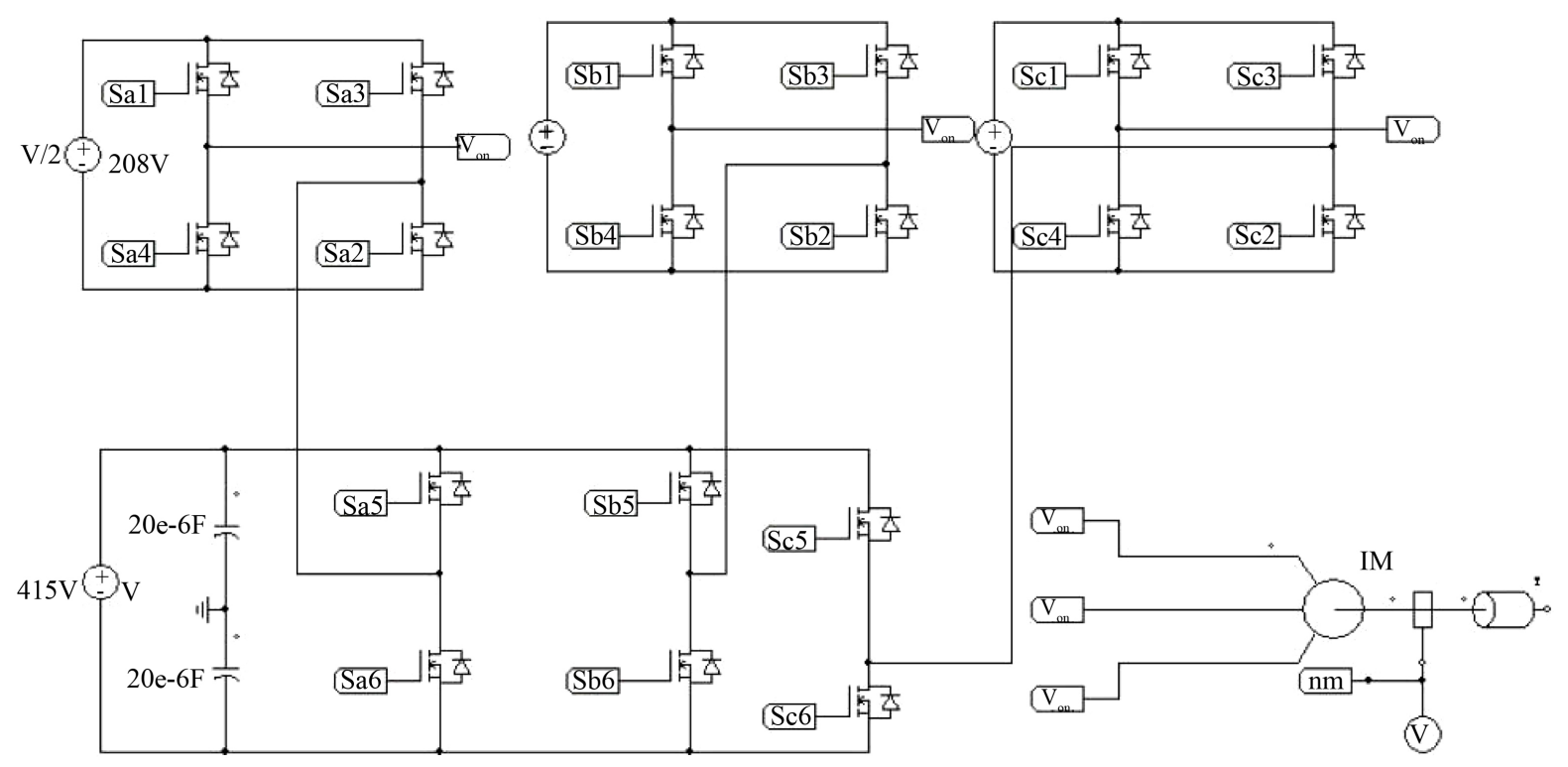

Figure 2. Simulation model of FLCHBMLI fed induction motor.

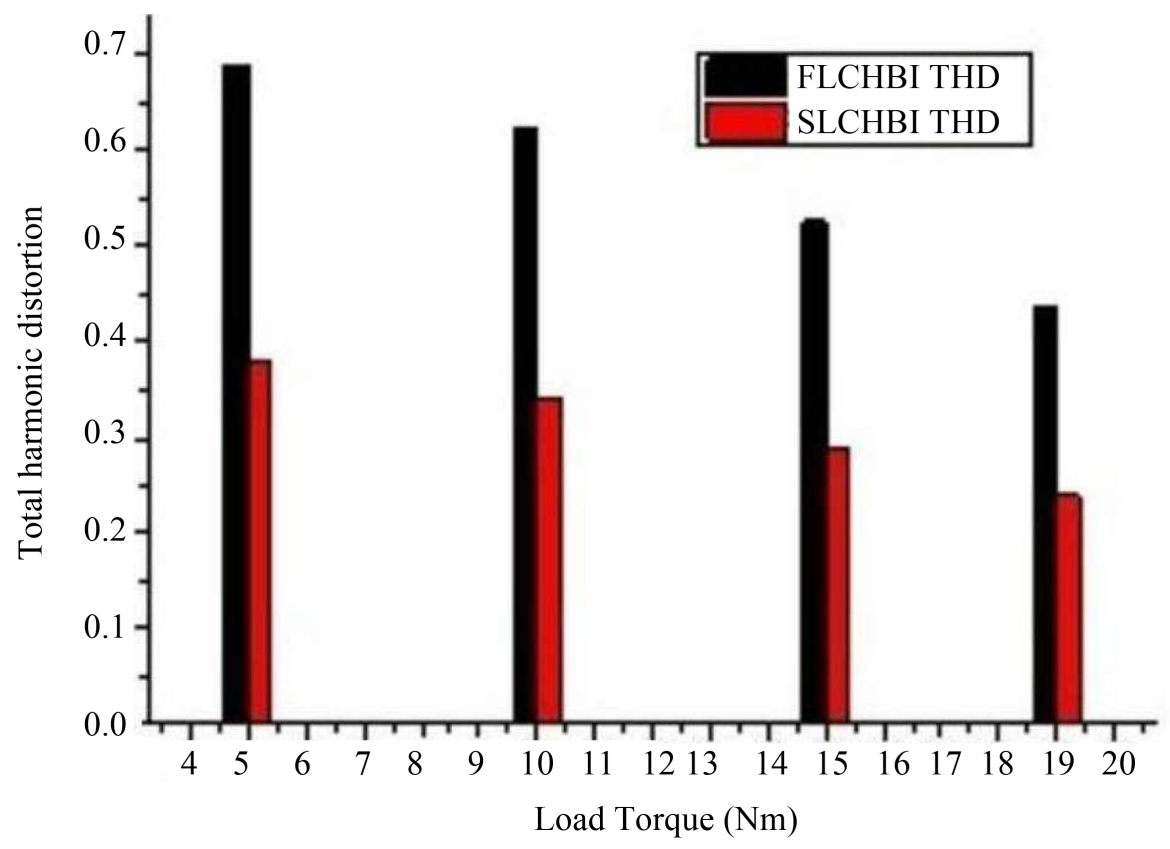

Figure 3. Total harmonic distortion Vs load torque for flchbmli and slchbmli.

The CHBMLI is then replaced by a DCMLI of three, five and seven levels and simulation study of DTC is repeated on the motor of same rating. A three phase three-level inverter requires twelve switching devices and six clamping diodes per leg as shown in Figure 4.

The comparison of the performance of the motor in terms of variation of THD with load torque for all the three types of inverters is shown in Figure 5. The THD is very small for SLDCI irrespective of the magnitude of the load. It takes less current at full load.

It is very clear from the simulation analysis that the THD decreases as the inverter level increases and hence it can be concluded that the performance of the induction motor fed by SLDCI is better when compared with the performance of FLDCI or TLDCI fed induction motor. Further, detailed analysis and hardware implementation for validating the results is carried out in closed loop form with a motor using TLDCI with SVM-DTC to reduce 


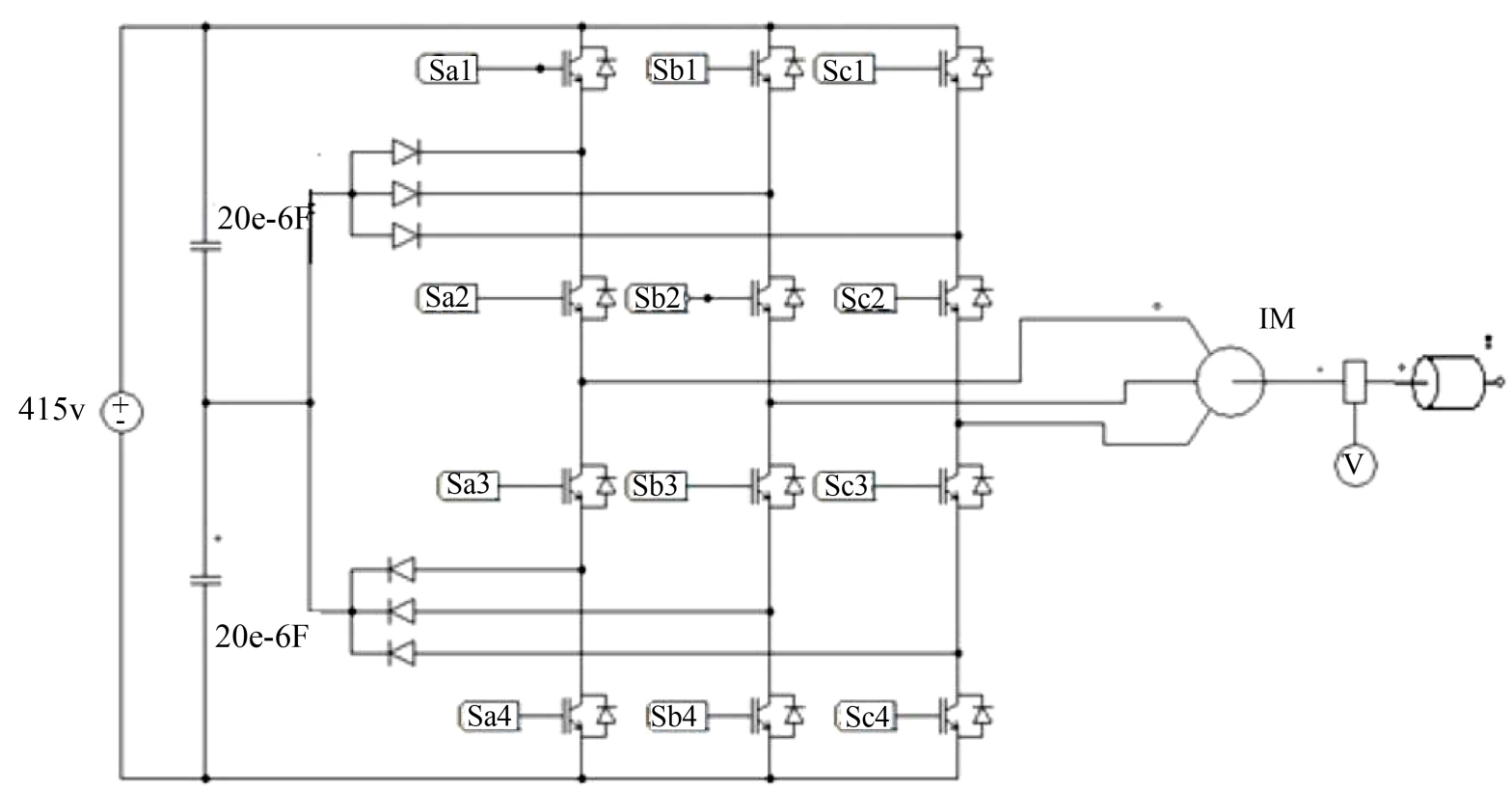

Figure 4. Simulation model of TLDCI fed induction motor.

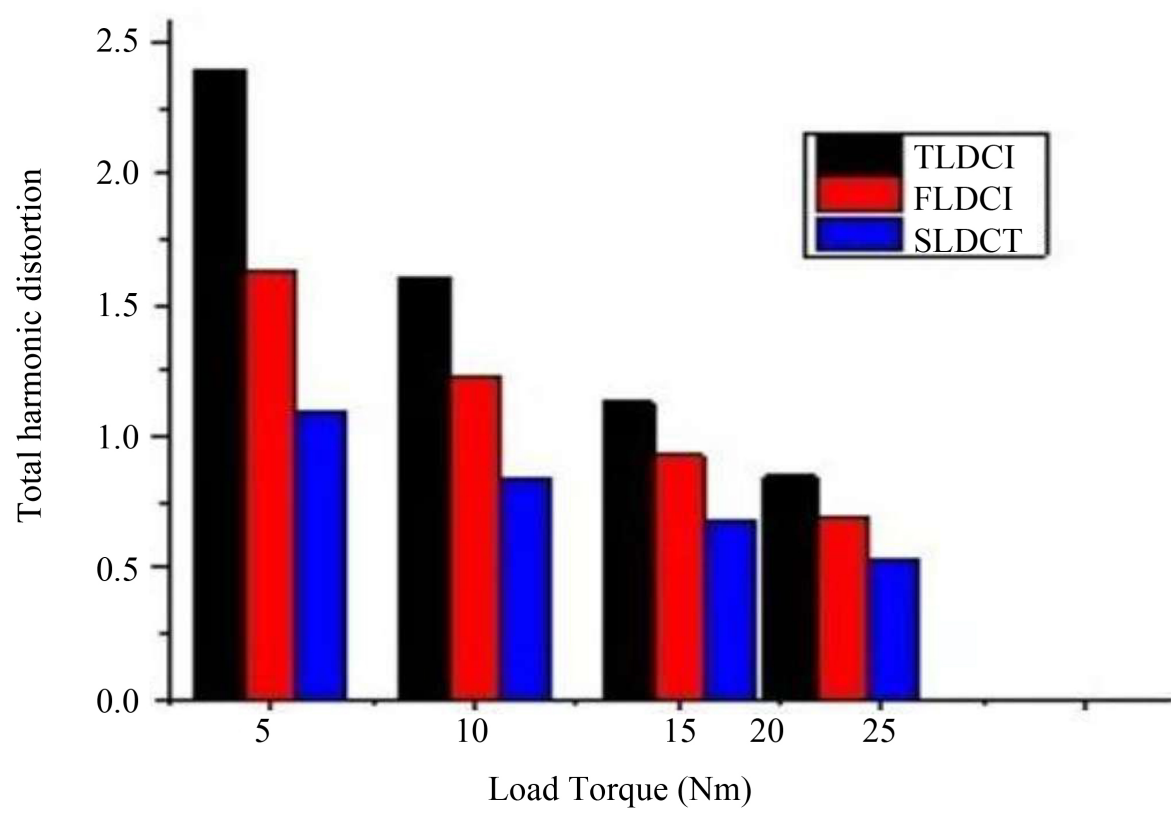

Figure 5. The variation of THD with load torque for TLDCI, FLDCI and SLDCI.

the investment cost.

\section{Three Level SVM Based DTC}

Direct flux and torque control with space vector modulation (DTC-SVM) schemes are proposed in order to improve the performance of classical DTC of Induction motor. The DTC-SVM strategy, as shown in Figure 6, operates at a constant switching frequency. The inverter is controlled, here, by space vector modulation technique instead of voltage sector selection block as used in classical DTC. The DTC-SVM strategy depends on the proposed flux and torque estimation block. The controller calculates the required stator voltage vector and then it is 
realized by space vector modulation technique. In this scheme two proportional integral (PI) type controllers are used, instead of hysteresis comparator, to regulate the torque and the flux.

Three level neutral point diode clamped inverter employed, in the proposed DTC scheme, is shown in Figure 7. The possible inverter switching states, for each phase is shown in Table 1.

Each leg has four active switches S1 to S4 with parallel diodes D1 to D4. The capacitors at the DC side are used to split the DC voltage to provide a neutral point Z. The clamping diodes Dz1 and Dz2 are connected to the neutral point. When switches S2 and S3 are closed, the output terminal A can be taken to the neutral through one of the clamping diodes. The voltage of each DC capacitor is E, which is equal to $V_{d} / 2$. A three-level inverter is characterized by 27 switching states as indicated in Figure 8, where the space vector diagram of three-level inverter is divided into six sectors (A, B, C, D, E and F). There are 24 active states, and three zero states which lie at the center of the hexagon. Each sector has four regions (1, 2, 3 and 4). The voltage vectors are classified into four groups such as zero vector, small vector, medium vector and large vector.

- Zero vector $\left(V_{0}\right)$, represents three switching states $\left[\begin{array}{lll}1 & 1 & 1\end{array}\right],\left[\begin{array}{lll}0 & 0 & 0\end{array}\right]$ and $\left[\begin{array}{lll}-1 & -1 & -1\end{array}\right]$. The magnitude of $V_{0}$ is Zero.

- Small vectors ( $V_{1}$ to $V_{6}$ ), have a magnitude of $V_{d} / 3$. Each small sector has two switching states 1 and -1 and they are classified as $\mathrm{P}$ or $\mathrm{N}$ type small vector.

- Medium vectors ( $V_{7}$ to $V_{12}$ ), have the magnitude of $\frac{V_{d}}{\sqrt{3}}$

- Large vectors ( $V_{13}$ to $V_{18}$ ), have the magnitude of $\frac{2}{3} V_{d}$

Table 1. Switching state of inverter.

\begin{tabular}{cccccc}
\hline \multirow{2}{*}{ Switching state } & \multicolumn{3}{c}{ Device switching status (Phase A) } & \multicolumn{2}{c}{ Inverter terminal voltage } \\
\cline { 2 - 5 } $\mathbf{V}_{\mathrm{AZ}}$
\end{tabular}

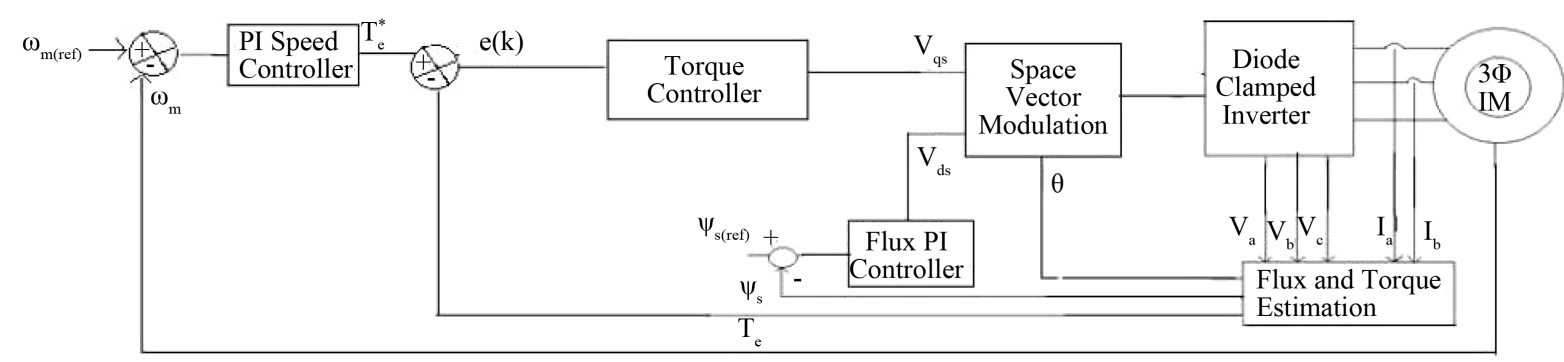

Figure 6. Block diagram of three level diode clamped inverter fed IM with DTC-SVM.

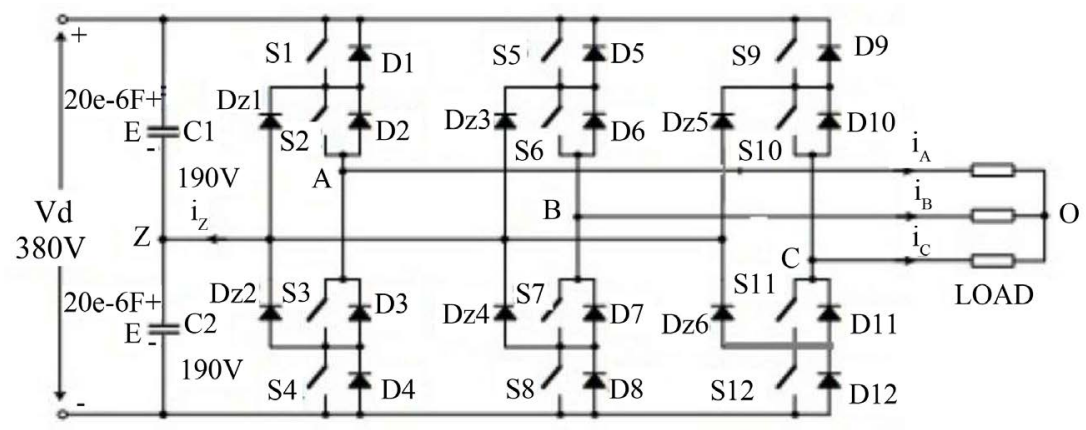

Figure 7. Three level neutral point diode clamped inverter. 
In Space Vector PWM (SVPWM), the voltage vector is approximately calculated by using three adjacent vectors in the given region.

\subsection{Calculation of Sector Number and Region}

In a three-level inverter, similar to a two-level inverter, each space vector diagram is divided into six sectors. The switching pattern explained for Sector I is same for all other sectors. Sector I is divided into four regions as shown in Figure 9 where all the possible switching states for each region are defined. Steps involved, in the SVPWM for three-level inverter, are sector determination, selection of the region in the sector, switching time calculation and the determination of switching intervals. The value of $\theta$ is calculated from $V_{d s}$ and $V_{q s}$ and then the sector in which the command vector $V_{\text {ref }}$ is located is determined. If $\theta$ is between

- $0^{\circ} \leq \theta<60^{\circ}$, Sector 1 ,

- $60^{\circ} \leq \theta<120^{\circ}$, Sector 2 ,

- $120^{\circ} \leq \theta<180^{\circ}$, Sector 3

- $180^{\circ} \leq \theta<240^{\circ}$, Sector 4 ,

- $240^{\circ} \leq \theta<300^{\circ}$, Sector 5 ,

- $300^{\circ} \leq \theta<360^{\circ}$, Sector 6 .

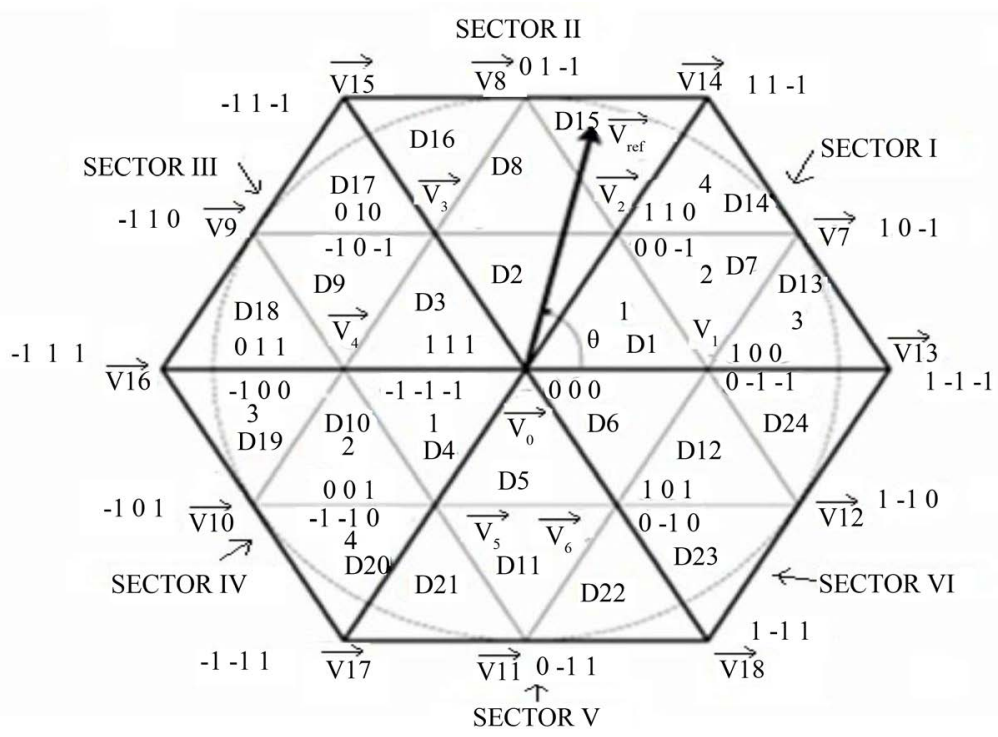

Figure 8. Space vector representations.

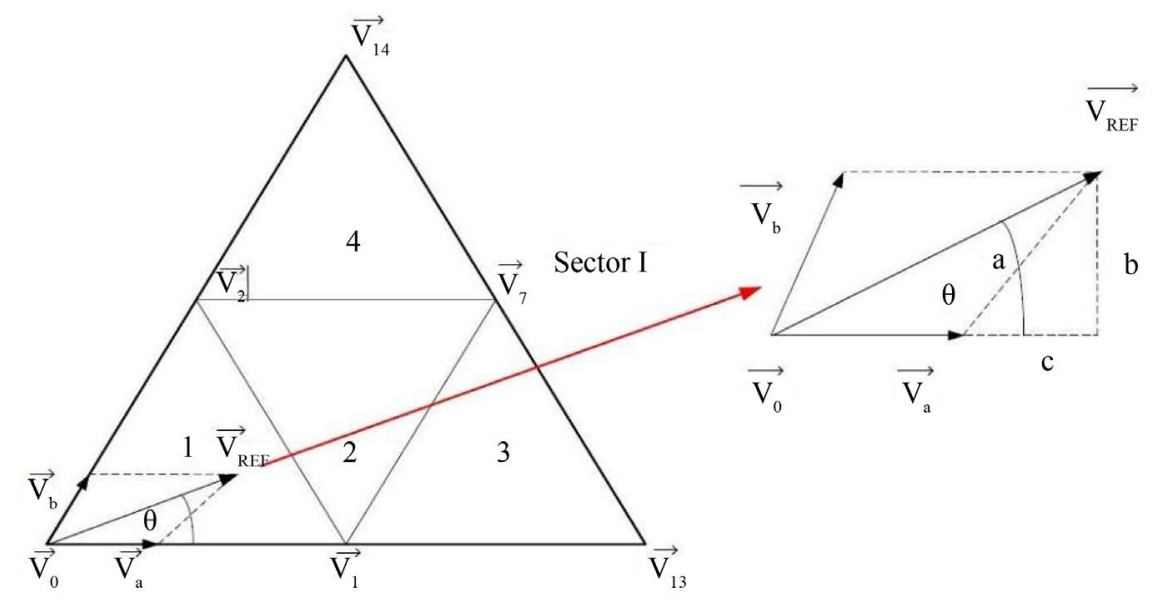

Figure 9. Sector I and its switching states for three-level inverter. 
However, the working region is identified as given below, using two additional vectors $\boldsymbol{V}_{a}$ and $\boldsymbol{V}_{b}$ which are defined as given in Equations (11) and (12).

$$
\begin{gathered}
\boldsymbol{V}_{a}=\boldsymbol{V}_{\text {ref }}\left(\cos \theta-\frac{\sin \theta}{\sqrt{3}}\right) \\
\boldsymbol{V}_{b}=2 * \boldsymbol{V}_{\text {ref }} \frac{\sin \theta}{\sqrt{3}}
\end{gathered}
$$

- If $\boldsymbol{V}_{a}, \boldsymbol{V}_{b}$ and $\left(\boldsymbol{V}_{a}+\boldsymbol{V}_{b}\right)$ are smaller than $0.33 V_{d}$, then $\boldsymbol{V}_{\text {ref }}$ is placed in region 1.

- If $\boldsymbol{V}_{a}$ and $\boldsymbol{V}_{b}$ are smaller than $0.33 V_{d}$ and $\left(\boldsymbol{V}_{a}+\boldsymbol{V}_{b}\right)$ is higher than $0.33 V_{d}$, and then $\boldsymbol{V}_{\text {ref }}$ is placed in region 2.

- If $\boldsymbol{V}_{a}$ is higher than $0.33 V_{d}$, then $\boldsymbol{V}_{\text {ref }}$ is placed in region 3.

- If $\boldsymbol{V}_{b}$ is higher than $0.33 V_{d}$, then $\boldsymbol{V}_{\text {ref }}$ is placed in region 4.

\subsection{Calculation of Time Duration}

The principle of SVPWM method is based on the command voltage vector which is approximately calculated by using three adjacent voltage vectors. The duration of each voltage vectors obtained by using voltage time equation of vector

$$
\begin{gathered}
T_{a} V_{1}+T_{b} V_{2}+T_{c} V_{0}=T_{s} V_{\text {ref }} \\
T_{a}+T_{b}+T_{c}=T_{s}
\end{gathered}
$$

where $V_{1}, V_{2}$ and $V_{0}$ are vectors that define the triangle region in which $V_{\text {ref }}$ is located. $T_{a}, T_{b}$ and $T_{c}$ are the corresponding vector durations and $T_{s}$ is the sampling time. $T_{a}, T_{b}$ and $T_{c}$ give the switching time for sector I as given in Table 2. The switching time period calculation is carried out is given in Table 3 and the switching sequences of thirteen segments for $V_{\text {ref }}$ in sector I region 1 is shown in Figure 10.

\subsection{Design of PI Controllers}

PI controller is the one which controls the dynamic performance of the machine. The gains of PI controllers for the torque and flux loops have to be tuned properly to minimize the torque ripple. In the proposed work, separate PI controllers are used for torque, flux and speed control of induction motor.

1) Torque PI controller

\section{Table 2. Switching time calculation.}

\begin{tabular}{ccc}
\hline & REGION 1 & REGION 2 \\
\hline$T_{a}$ & $T_{s}\left[2 M \sin \left(\frac{\pi}{3}-\theta\right)\right]$ & $T_{s}[1-2 M \sin \theta]$ \\
$T_{b}$ & $T_{s}\left[1-2 M \sin \left(\frac{\pi}{3}-\theta\right)\right]$ & $T_{s}\left[2 M \sin \left(\frac{\pi}{3}+\theta\right)-1\right]$ \\
$T_{c}$ & $T_{s}[2 M \sin (\theta)]$ & $T_{s}\left[2-2 M \sin \left(\frac{\pi}{3}-\theta\right)\right]$ \\
$T_{a}\left[2-2 M \sin \left(\frac{\pi}{3}+\theta\right)\right]$ & REGION 4 \\
$T_{b}$ & $T_{s}[2 M \sin (\theta)]$ & $T_{s}[2 M \sin (\theta)-1]$ \\
$T_{c}\left[2 M \sin \left(\frac{\pi}{3}-\theta\right)-1\right]$ & $T_{s}\left[2 M \sin \left(\frac{\pi}{3}-\theta\right)\right]$ \\
\hline
\end{tabular}


Table 3. Switching intervals for different regions of Sector I.

\begin{tabular}{|c|c|c|c|c|}
\hline Intervals & Region 1 & Region2 & Region3 & Region4 \\
\hline 1 & $T_{b} / 8$ & $T_{a} / 6$ & $T_{a} / 4$ & $T_{c} / 4$ \\
\hline 2 & $T_{a} / 4$ & $T_{b} / 3$ & $T_{d} / 2$ & $T_{b} / 2$ \\
\hline 3 & $T_{c} / 4$ & $T_{c} / 3$ & $T_{b} / 2$ & $T_{a} / 2$ \\
\hline 4 & $T_{b} / 4$ & $T_{a} / 3$ & $T_{a} / 2$ & $T_{d} / 2$ \\
\hline 5 & $T_{a} / 4$ & $T_{c} / 3$ & $T_{b} / 2$ & $T_{a} / 2$ \\
\hline 6 & $T_{c} / 4$ & $T_{a} / 3$ & $T_{c} / 2$ & $T_{b} / 2$ \\
\hline 7 & $T_{b} / 4$ & $T_{b} / 2$ & $T_{a} / 4$ & $T_{d} / 4$ \\
\hline 8 & $T_{c} / 4$ & $T_{c} / 3$ & & \\
\hline 9 & $T_{a} / 4$ & $T_{a} / 6$ & & \\
\hline 10 & $T_{b} / 4$ & & & \\
\hline 11 & $T_{c} / 4$ & & & \\
\hline 12 & $T_{a} / 4$ & & & \\
\hline 13 & $T_{b} / 8$ & & & \\
\hline
\end{tabular}

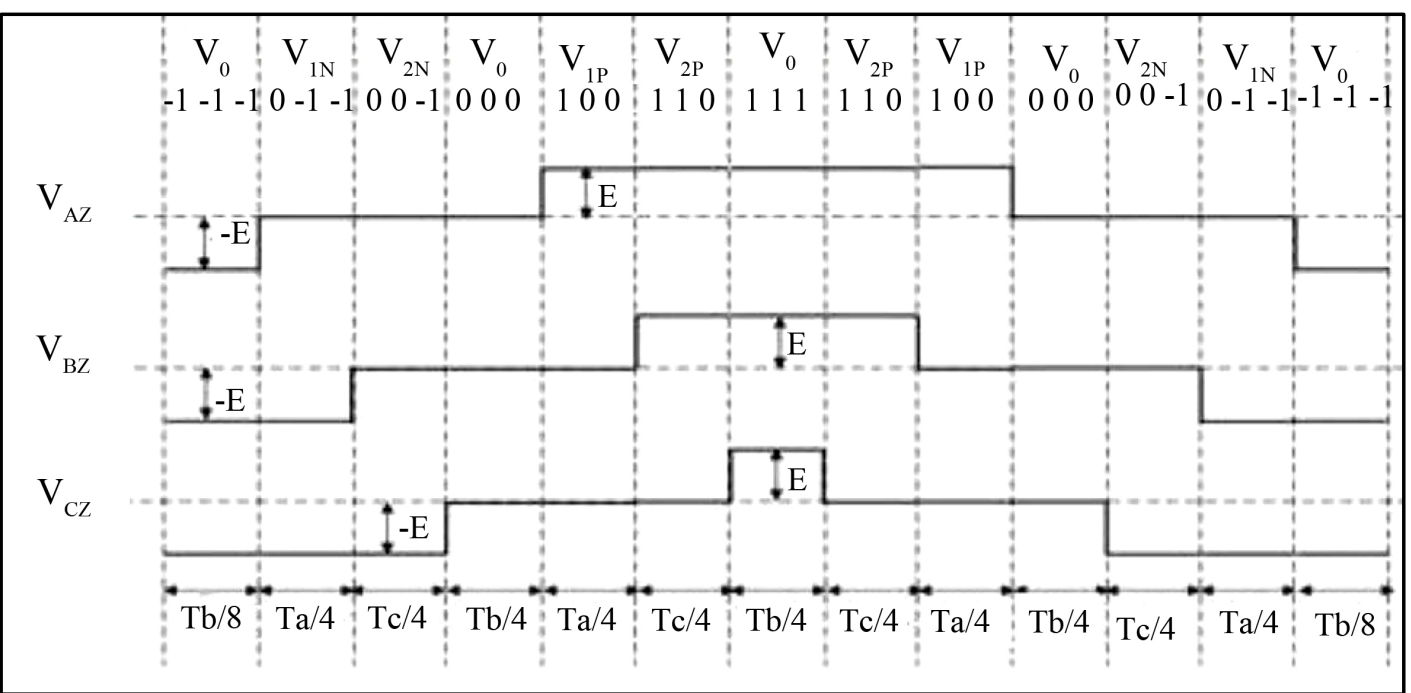

Figure 10. Switching sequence when V ref in region 1 of sector I.

Motor Equation from (1) to (8) can be modified and written as given in Equations (15) to (17).

$$
\begin{aligned}
\left(\left(R_{s} L_{r}+R_{r} L_{s}\right)+\sigma L_{s} L_{r} \frac{\mathrm{d}}{\mathrm{d} t}\right) I_{q s} & =L_{r} V_{d s}-L_{r} \psi_{s} p \omega_{m}+I_{d s} \sigma L_{s} L_{r}\left(\omega_{s s}-p \omega_{m}\right) \\
\sigma & =1-\frac{L_{m}^{2}}{L_{s} L_{r}}
\end{aligned}
$$

The last term in the right side of above equation is negligibly small and it can be considered as zero compared to the values of other terms.

$$
\begin{gathered}
I_{d s} \sigma L_{s} L_{r}\left(\omega_{s s}-p \omega_{m}\right) \approx 0 \\
\left(\left(R_{s} L_{r}+R_{r} L_{s}\right)+\sigma L_{s} L_{r} \frac{\mathrm{d}}{\mathrm{d} t}\right) I_{q s}=L_{r} V_{d s}-L_{r} \psi_{s} p \omega_{m}
\end{gathered}
$$


Under no load condition the change in motor speed can be expressed as shown in Equation (18).

$$
\frac{\mathrm{d} \omega_{m}}{\mathrm{~d} t}=\frac{3}{2} \frac{1}{J} p \psi_{s} I_{d s}
$$

The current $I_{q s}$ can be expressed as shown in Equation (19).

$$
\begin{gathered}
I_{q \mathrm{~s}}=\frac{2}{3} \frac{T_{e}}{p \psi_{s}} \\
\left(\left(R_{s} L_{r}+R_{r} L_{s}\right) \frac{\mathrm{d}}{\mathrm{d} t}+\sigma L_{s} L_{r}\left[\frac{\mathrm{d}}{\mathrm{d} t}\right]^{2}\right) I_{q s}=L_{r} \frac{\mathrm{d} V_{d s}}{\mathrm{~d} t}-L_{r} \psi_{s} p \frac{\mathrm{d} \omega_{m}}{\mathrm{~d} t}
\end{gathered}
$$

Based on the equations of the motor, the open loop transfer function can be expressed as

$$
G_{T}(s)=\frac{A s}{s^{2}+B s+C}
$$

where the constants $A, B$ and $C$ are defined as given in Equations (22) to (24).

$$
\begin{gathered}
A=\frac{3 p \psi_{s}}{2 \sigma L_{s}} \\
B=\frac{R_{s} L_{r}+R_{r} L_{s}}{\sigma L_{s} L_{r}} \\
C=\frac{3}{2} \frac{p^{2} \psi_{s}^{2}}{\sigma L_{s} J} \\
\frac{T_{e}}{T_{e}^{*}}=\left(\frac{3358 K_{p} s+3358 K_{i}}{s^{2}+\left(14495+3358 K_{p}\right) s+57675+3358 k_{i}}\right)
\end{gathered}
$$

Closed loop block diagram for the torque PI Controller is shown in Figure 11. The parameters $K_{p}$ and $K_{i}$ of the PI controller are calculated assuming the values of settling time $t_{s}$ and peak overshoot Mp such that $t_{s} \leq 0.003$ sec and maximum peak overshoot $\mathrm{Mp} \leq 2 \%$. The values of $K_{p}$ and $K_{i}$ are obtained 1.5 and 100 respectively. Similarly, the parameters of PI Controller for flux and speed are calculated. The value of $K_{p}$ for flux and speed controller are 4441 and 187.56. The value of $K_{i}$ for flux and speed controller are 107.38 and 132.38 respectively.

\section{Simulation of TLDCI Fed IM with PI Controller}

An induction motor of rating $0.75 \mathrm{~kW}$ is considered for analysis. The inverter used here is a Three Level Diode Clamped Inverter(TLDCI). The simulation of TLDCI fed IM with DTC-SVM with torque controller is performed using MATLAB software. The motor is started and run on no load at a speed of $1500 \mathrm{rpm}$ and a load of $5 \mathrm{Nm}$ is applied at 0.25 seconds. The speed drops to $1478 \mathrm{rpm}$ and settles at $1500 \mathrm{rpm}$ within 0.005 seconds as shown in Figure 12. The steady state voltage and line current waveforms are shown in Figure 13 and Figure 14 respectively.

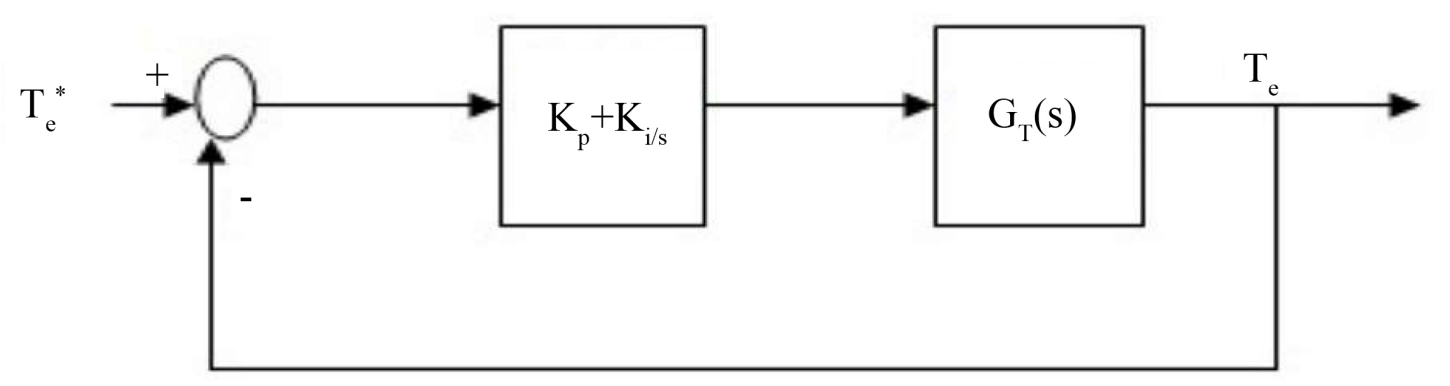

Figure 11. Block diagram of PI torque controller. 


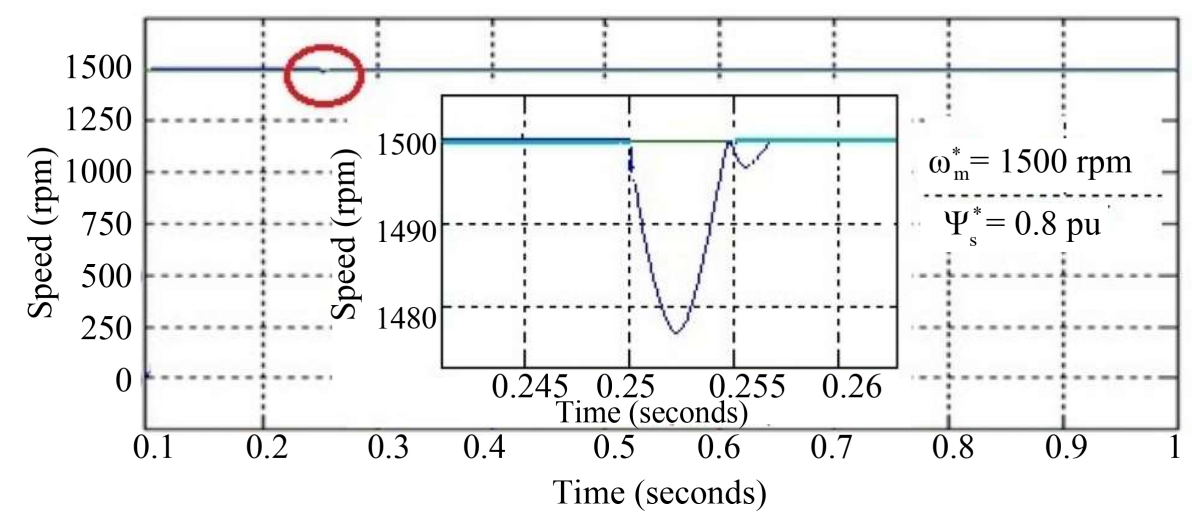

Figure 12. Speed response of $0.75 \mathrm{~kW}$ IM when load applied at 0.25 seconds with PI controller.

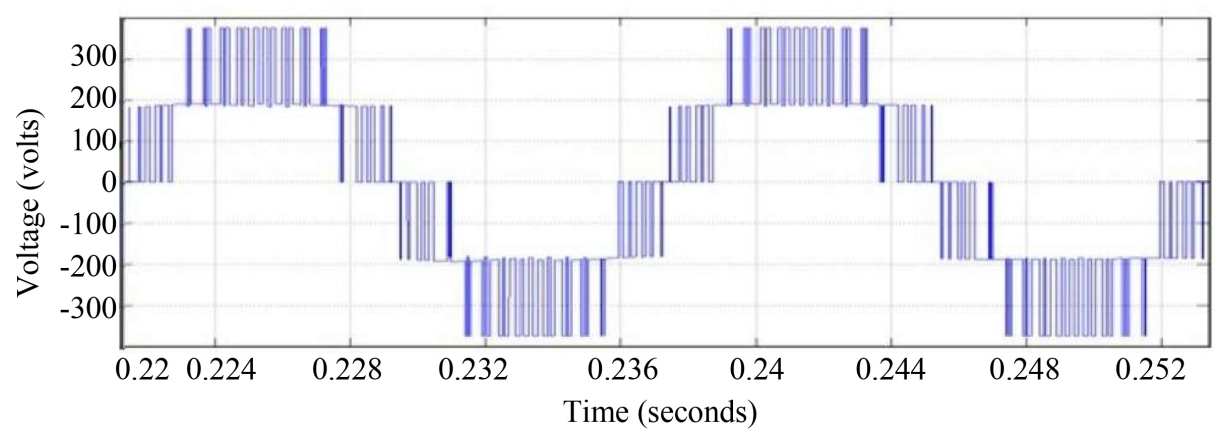

Figure 13. Line voltage $V_{a b}$ of TLDCI fed IM with PI controller.

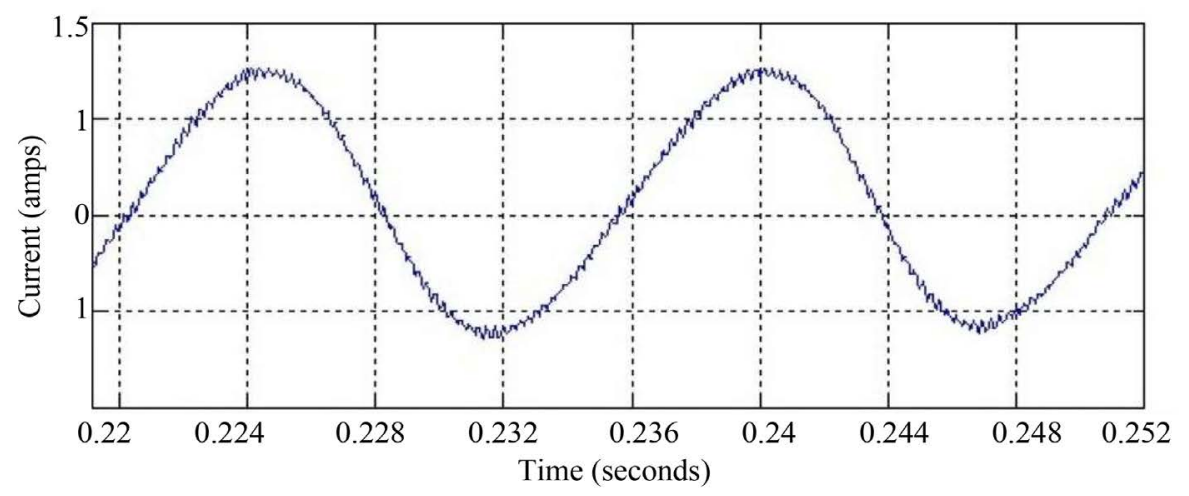

Figure 14. Phase A current waveform of TLDCI fed IM with PI controller for 5 Nm load torque.

The load on the motor is, then, reduced to $3 \mathrm{Nm}$ at $0.45 \mathrm{sec}$ and the corresponing torque response is shown in Figure 15. The torque ripple at 5Nm is shown in Figure 16.

Due to unexpected load changes or environmental factors, the motor shaft vibrates and produces oscillations in the motor speed and torque until it reaches the set speed. The presence of these oscillations reduce the performance of the machine. The PI controller is replaced by fuzzy logic controller with a view to improving the performance

\section{Design of Fuzzy Logic Controller for the Proposed Work}

Fuzzy logic control is the process of formulating the mapping from a given input to an output using fuzzy logic. The classical PI controller is replaced by fuzzy logic controller (FLC) to improve the performance. The torque controller shown in Figure 1 is replaced by fuzzy torque controller with three level space vector modulation 


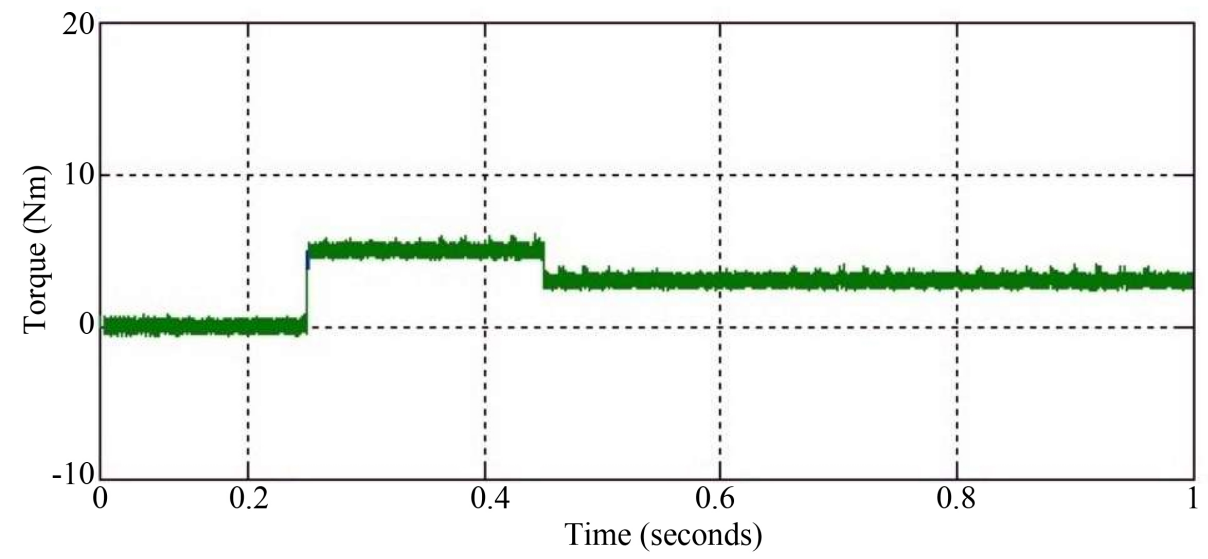

Figure 15. Electromagnetic torque responses when $T_{L}$ is changed to $3 \mathrm{Nm}$ for TLDCI fed IM with PI controller.

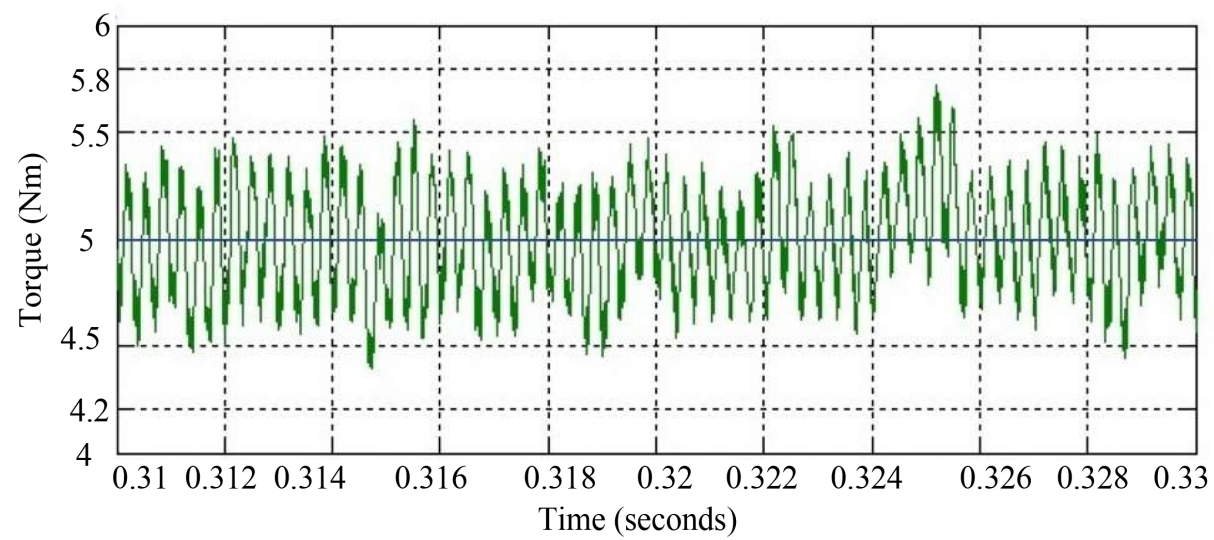

Figure 16. Torque ripple for 5 Nm torque applied for TLDCI fed IM with PI controller.

based DTC drive. The FLC is designed with the knowledge of the response of the system obtained with PI controllers. The error and the change in error obtained from the reference torque and simulated torque are scaled and fed to the fuzzy logic controller. The scaling factor for change in error is $1 / 30$ and for the output, it is 17 . The FLC controller is designed to give the change in crisp voltage $c V_{q s}$ and it is integrated to get the voltage $V_{q s}$. By controlling the torque and flux amplitude, a gate signal for inverter is generated. The Equations (25) to (28) are used in the implementation of the FLC scheme.

$$
\begin{gathered}
c V_{q s}(k)=F L C[e(k), c e(k)] \\
V_{q s}(k)=c V_{q s}(k)+V_{q s}(k-1) \\
e(k)=T^{*} T_{e} \\
c e(k)=e(k)-e(k-1)
\end{gathered}
$$

The inputs $e(k)$ and $c e(k)$ are mapped to the FLC to generate the change in the voltage $c V_{q s}$ as the output. The fuzzy set $\mathrm{L}$ for the error and change in error is defined as

$$
L=\text { [NB, NM, NS, ZE, PS, PM, PB] }
$$

The input variables are the error $(e)$ and the change in error $(c e)$ of the torque. The error variable is quantized into seven fuzzy set as Negative Small NS, Negative Medium NM, Negative Big NB, Zero Z, Positive Small PS, Positive Medium PM and Positive Big PB. All the membership functions chosen are of the triangular type. The 
membership function of the fuzzy controller input variables and output variable are shown in Figures 17-19. The rules of the fuzzy controller are shown in Table 4.

The simulation of TLDCI fed IM of DTC-SVM with fuzzy controller is performed using MATLAB software. The motor is started at no load and a load torque of $5 \mathrm{Nm}$ is applied at $0.25 \mathrm{sec}$, the speed oscillates for short duration and settles at set speed of 1500 rpm and the response is shown in Figure 20.

The load on the motor is reduced to $3 \mathrm{Nm}$ at $0.45 \mathrm{sec}$ and the torque response is shown in Figure 21. The torque ripple at $5 \mathrm{Nm}$ load is shown in Figure 22 as $14.33 \%$. Table 5 gives the values of torque ripple for various speeds in both cases.

Table 5 shows the simulated torque ripple of PI and Fuzzy controller for different set speeds at constant load torque of $5 \mathrm{Nm}$. It is very clear that the percentage of torque ripple calculated for $5 \mathrm{Nm}$ load torque for fuzzy controller are much less than the PI controller.

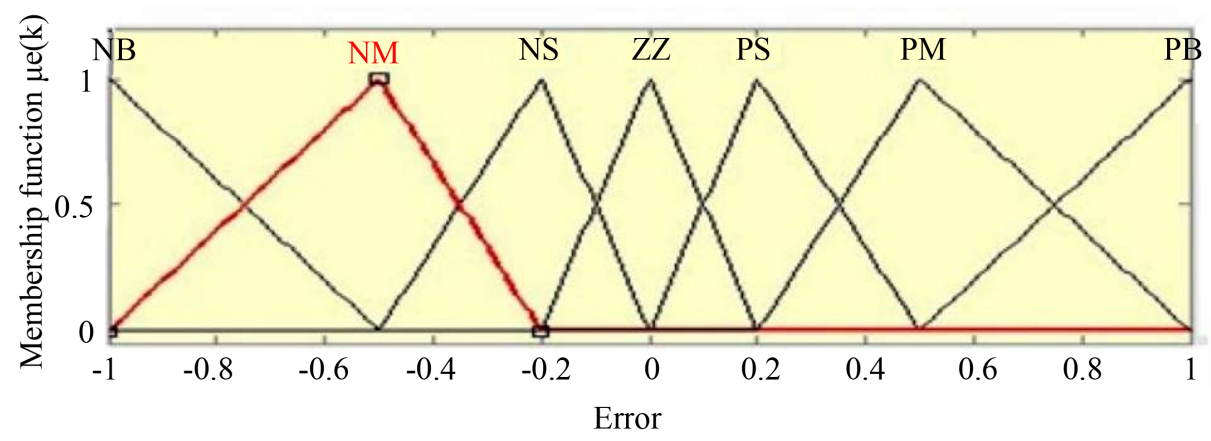

Figure 17. Membership function for input variable "error”.

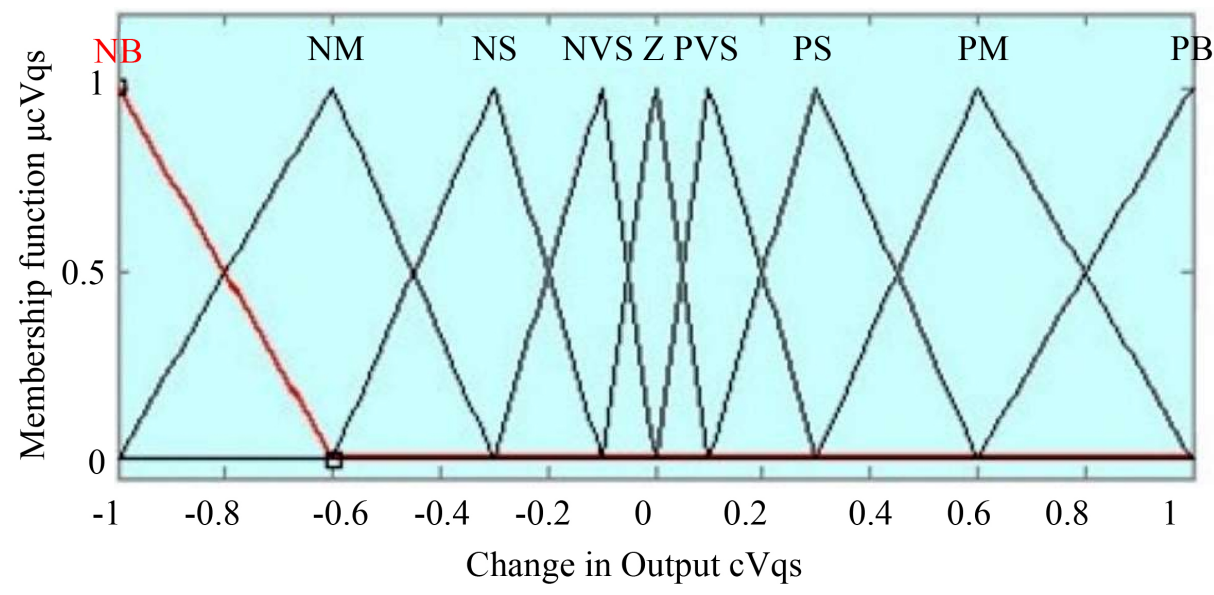

Figure 18. Membership function for input variable "Change in error”.

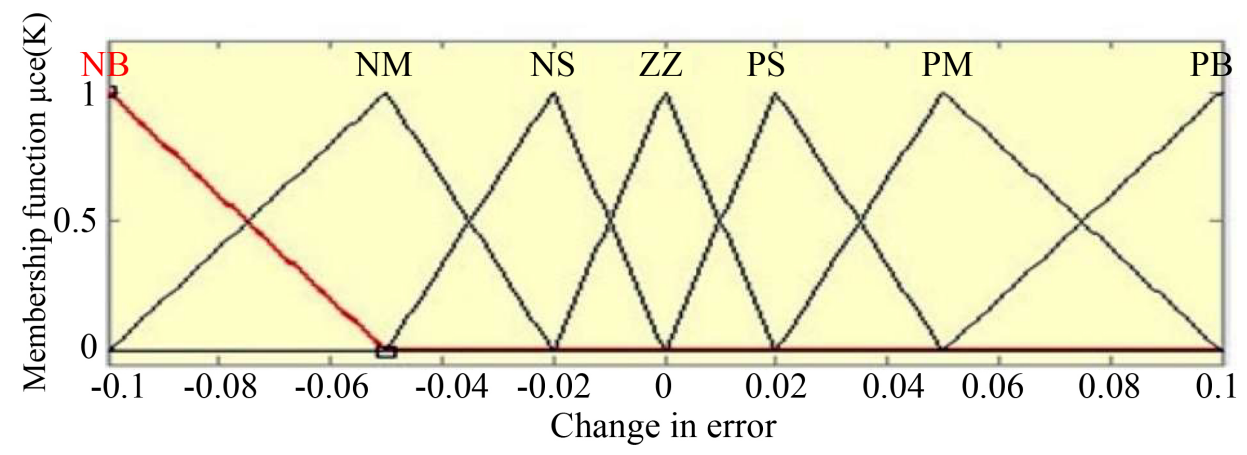

Figure 19. Membership function for output variable $c V_{q s}$. 


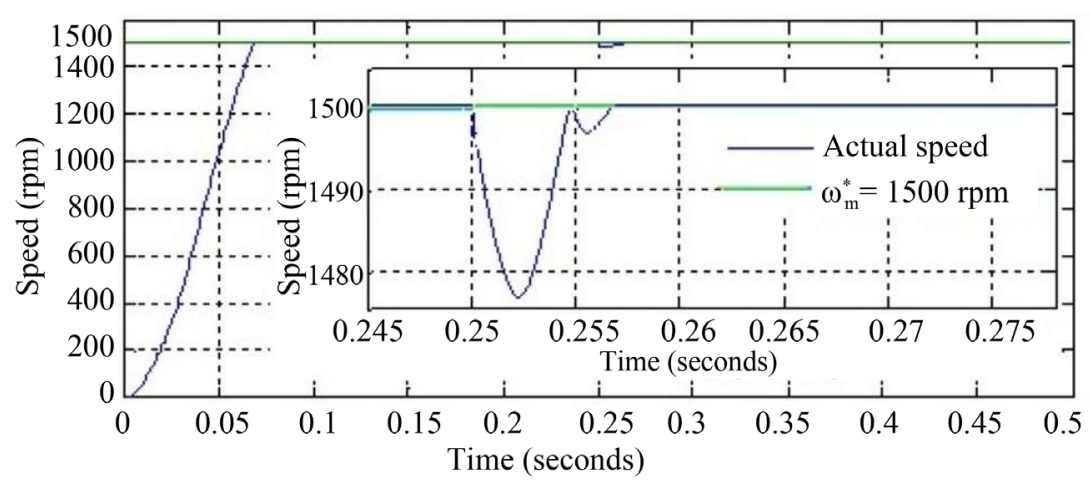

Figure 20. Speed response when $5 \mathrm{Nm}$ load applied at $0.25 \mathrm{sec}$ with fuzzy controller.

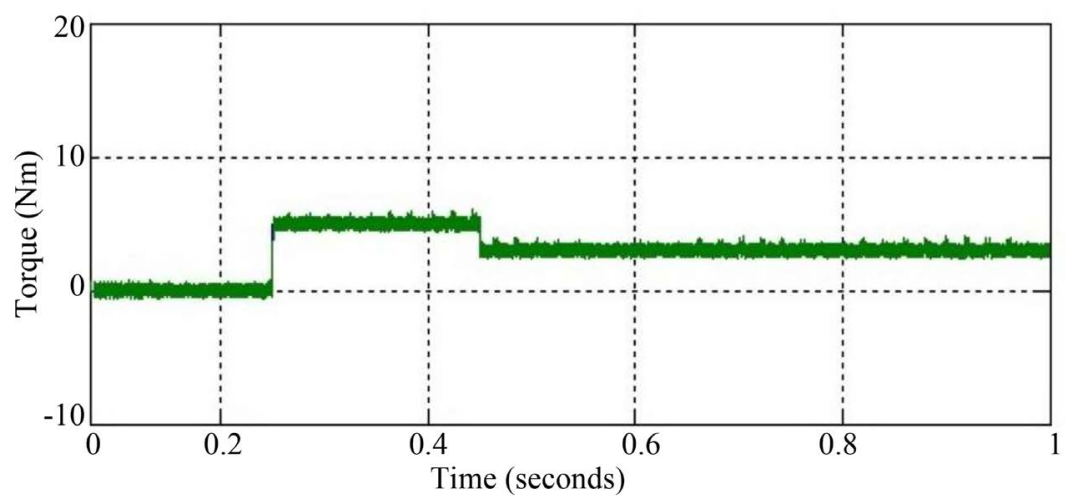

Figure 21. Torque response of $0.75 \mathrm{~kW}$ IM with fuzzy controller.

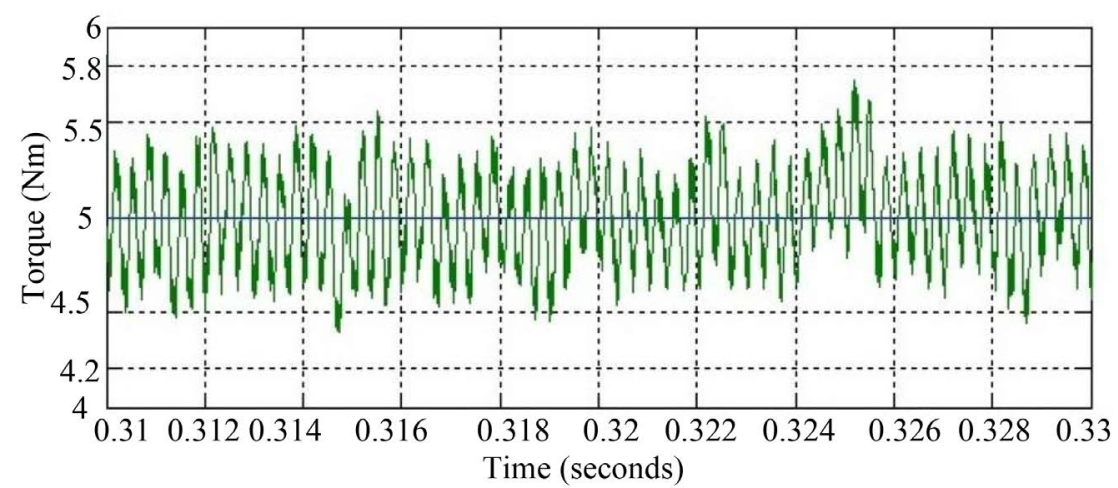

Figure 22. Torque ripple of $5 \mathrm{Nm}$ load torque with fuzzy controller.

Table 4. Rule base for the output.

\begin{tabular}{cccccccc}
\hline E & NB & NM & NS & Z & PS & PM & PB \\
NB & NB & NB & NB & NM & NS & NVS & Z \\
NM & NB & NB & NM & NS & NVS & Z & PVS \\
NS & NB & NM & NS & NVS & Z & PVS & PS \\
Z & NM & NS & NVS & Z & PVS & PS & PM \\
PS & NS & NVS & Z & PVS & PS & PM & PB \\
PM & NVS & Z & PVS & PS & PM & PB & PB \\
PB & Z & PVS & PS & PM & PB & PB & PB \\
\hline
\end{tabular}


Table 5. Comparison of torque ripple with PI and fuzzy controllers.

\begin{tabular}{lcccc}
\hline \multirow{2}{*}{ Machine } & \multirow{2}{*}{$\begin{array}{c}\text { Speed } \\
(\mathbf{r p m})\end{array}$} & Load Torque (Nm) & PI Controller & Torque ripple (\%) \\
\cline { 3 - 5 } & 1000 & 5 & 24.30 & 17.84 \\
$0.75 \mathrm{~kW}$ & 1200 & 5 & 22.34 & 16.91 \\
& 1500 & 5 & 21.78 & 14.33 \\
\hline
\end{tabular}

\section{Hardware Implementation of Three Level SVM Based DTC}

Hardware implementation of three level diode clamped inverter fed induction motor using DTC-SVM is carried out in the laboratory with a view to validate the simulation results of PI and fuzzy controllers. The block diagram of the experimental set up of $0.75 \mathrm{~kW}$ TLDCI fed IM with DTC-SVM using DSP processor as shown in Figure 23. It consists of one optocoupler, voltage and current sensors, speed sensor, frequency to voltage converter $(\mathrm{F} / \mathrm{V})$, signal conditioner, protection circuit and FPGA processor. The optocoupler is used for isolating the input PWM signals between the FPGA processor and the power circuit of diode clamped inverter. Voltage and current sensors are used to measure the dc link voltage, dc link current and line current of the diode clamped inverter. The Hall Effect sensors are used for sensing the current and voltage. Hall Effect current transducers sense the currents $I_{d}, I_{a}, I_{b}, I_{c}$ and one hall effect voltage transducer senses the DC link voltage $\left(V_{d}\right)$. The speed sensor is used to measure the speed of the induction motor in terms of frequency of square wave which is fed to a frequency to voltage converter circuit. The signal conditioner circuit is used to convert the current and voltage signals combatable with the protection circuit and the ADC of the DSP processor. The protection circuit is used to provide protection against over voltage, over current and under voltage. The current and voltage obtained from signal conditioners are given to the ADC inputs of DSP. The space vector modulation scheme is implemented in DSP processor. The schematic diagram for firing pulse and protection circuit is shown in Figure 24 and the switching sequence for phase A is shown in Figure 25. The experimental waveforms are measured using digital storage oscilloscope (DSO). The experiment is initially carried with PI controller. A load of $5 \mathrm{Nm}$ is applied at 0.25 seconds and then reduced to $3 \mathrm{Nm}$ at 0.45 seconds. The corresponding torque response is shown in Figure 26. The torque response of FLC torque control on DTC-SVM tuned motor is shown in Figure 27. The line voltage and current waveform under load torque of $3 \mathrm{Nm}$ is shown in Figure 28 and Figure 29. The torque ripple at 5 Nm using PI controller and fuzzy controller is shown in Figure 30 and Figure 31 and the measured torque ripple is $14.28 \%$.

The speed response is shown in Figure 32 for a reduction in load torque at $t=0.45$ sec. It is clear from the speed response that the drive maintains the set speed $1500 \mathrm{rpm}$ even during load variations for PI controller and the corresponding experimental speed response for fuzzy controler is shown in Figure 33 where the speed drops and then settles at set speed of $1500 \mathrm{rpm}$. The experiment is repeated for $1200 \mathrm{rpm}$ and $1000 \mathrm{rpm}$ and the torque ripple at these conditions are measured.

Table 6 shows the calculated experimental torque ripple of PI and Fuzzy controller for different set speeds at constant load torque of $5 \mathrm{Nm}$. Figure 34 is the snap shot of the experimental set up.

On comparing the simulation results in Table 5 with those obtained from experimental set up shown in Table 6, it is very clear that the results are very closely matched and hence the proposed scheme is validated.

The above simulation method is extended to $3 \mathrm{~kW}$ machine and the performance analysis is as explained below.

\section{Analysis of 3 kW Induction Motor}

An induction motor drive of rating $3 \mathrm{~kW}$ is fed with TLDCI fed DTC-SVM with PI controller run at no load at a speed of 1500 RPM and a load torque of $15 \mathrm{Nm}$ is applied at 0.25 seconds. The electromagnetic torque reaches the steady state value of $15 \mathrm{Nm}$ at $\mathrm{t}=0.257 \mathrm{~s}$ after the decay of transients and then reduced to $10 \mathrm{Nm}$ at 0.45 seconds. The corresponding torque response is shown in Figure 35. The speed response for a load torque of 15 Nm applied at 0.25 seconds is shown in Figure 36. The torque ripple corresponding to 15 Nm load are shown in 


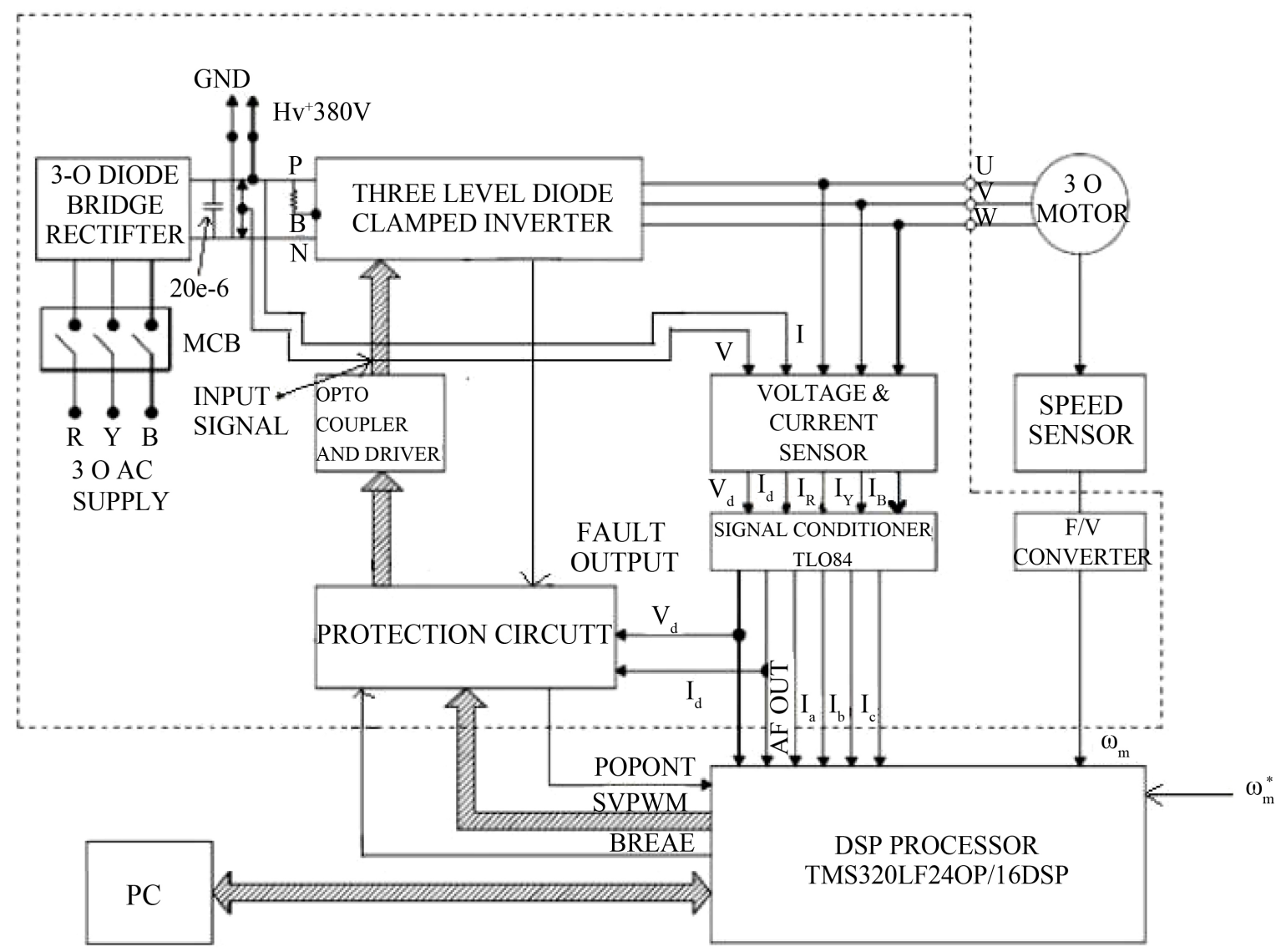

Figure 23. Block diagram of TLDCI fed IM with DTC-SVM for experimental setup.

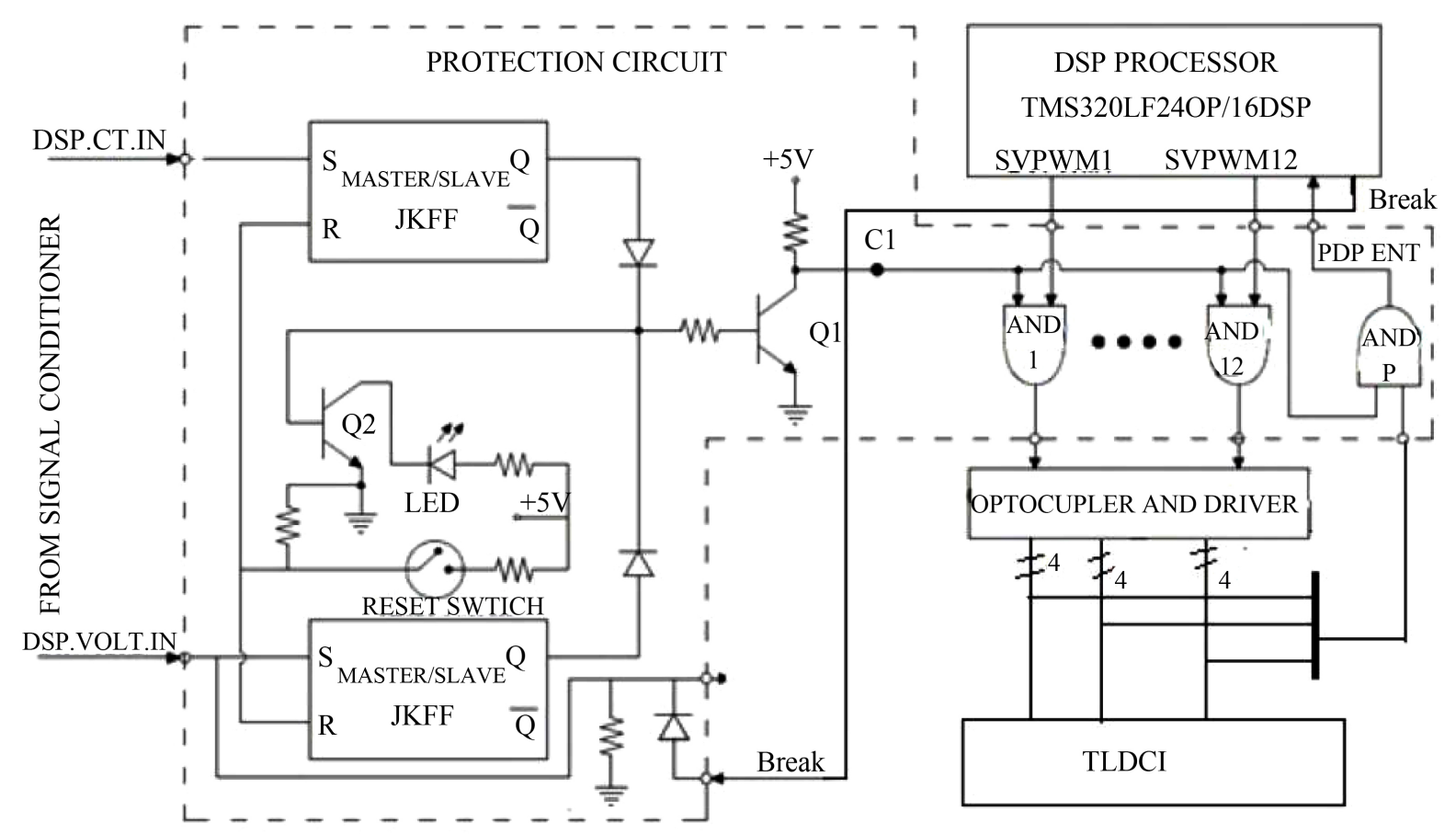

Figure 24. Firing pulse and protection circuit for SVPWM. 

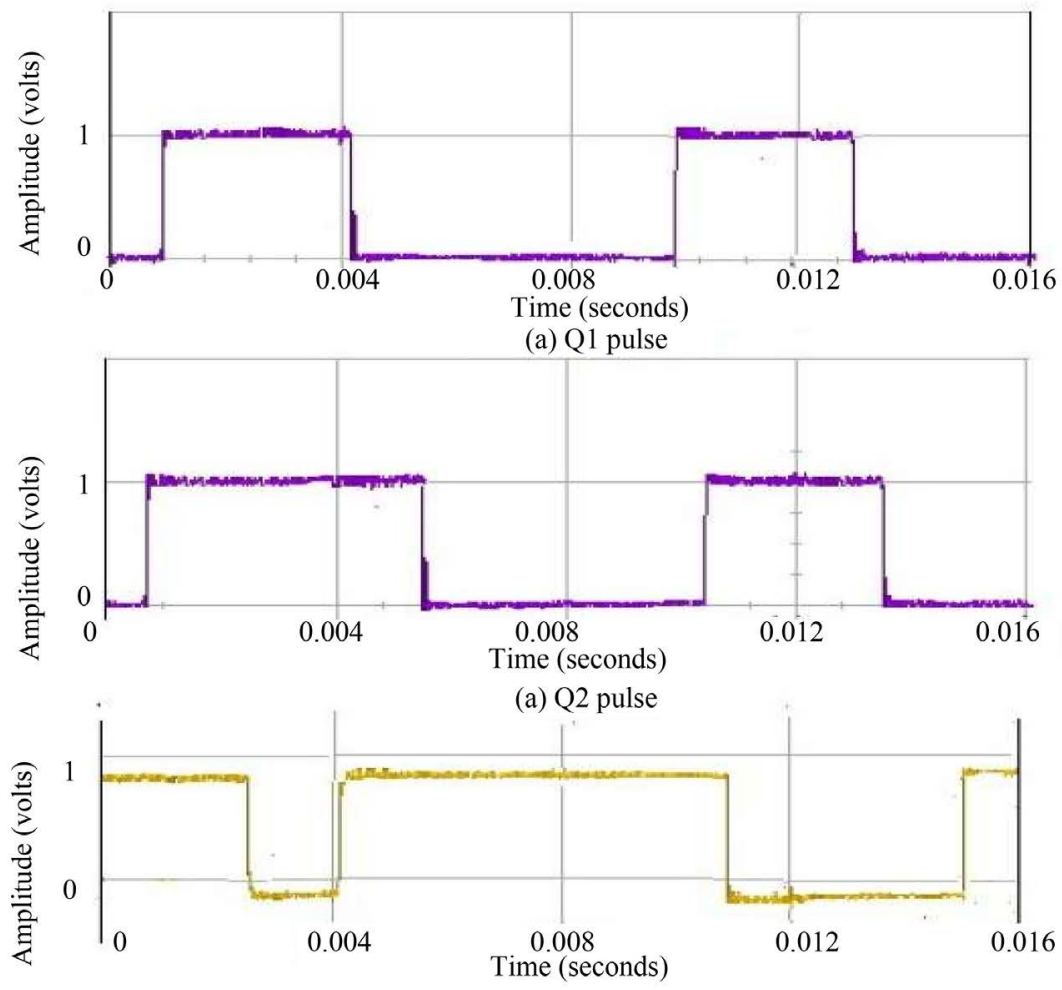

(a) Q3 pulse

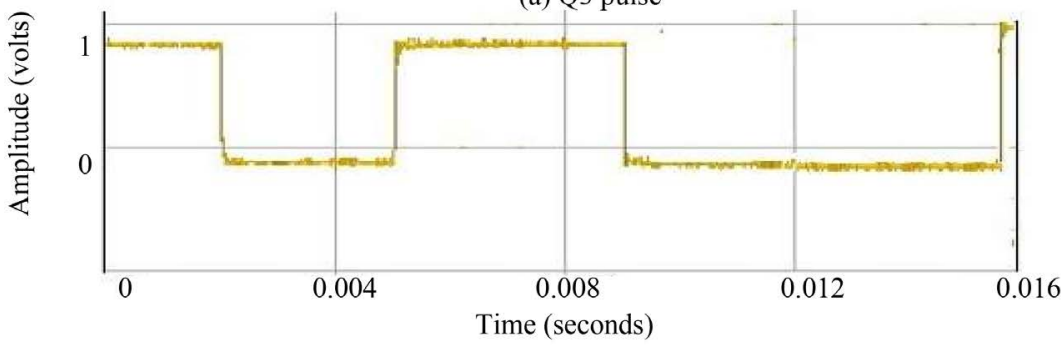

(a) Q4 pulse

Figure 25. Switching pulses for phase A using SVPW technique.

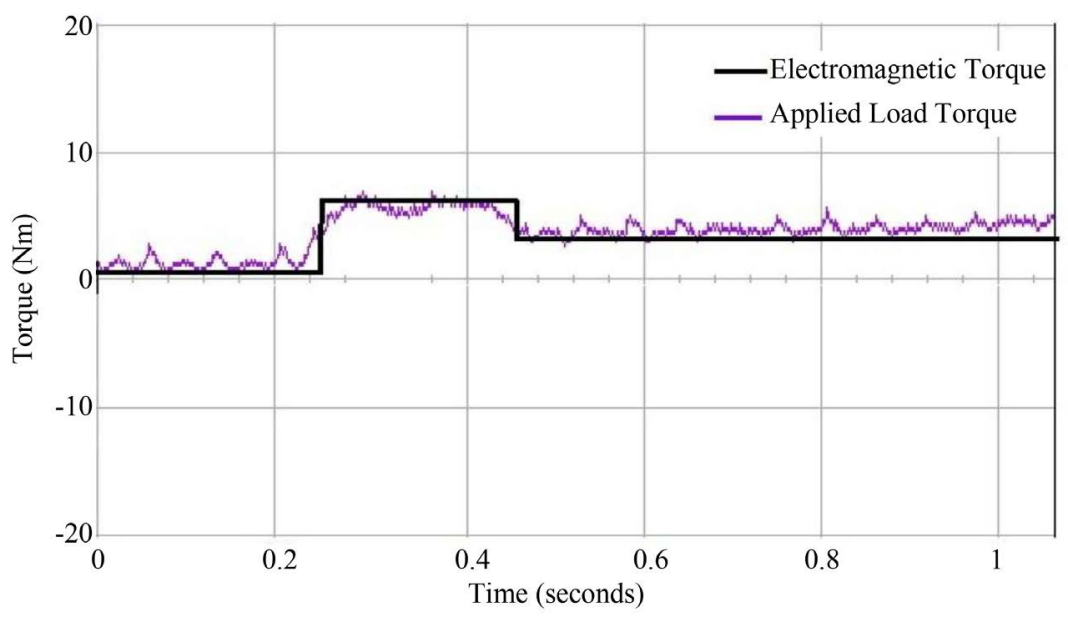

Figure 26. Torque respons when $5 \mathrm{Nm}$ is applied at $0.25 \mathrm{sec}$ and reduced to $3 \mathrm{Nm}$ at 0.45 sec for PI controller. 


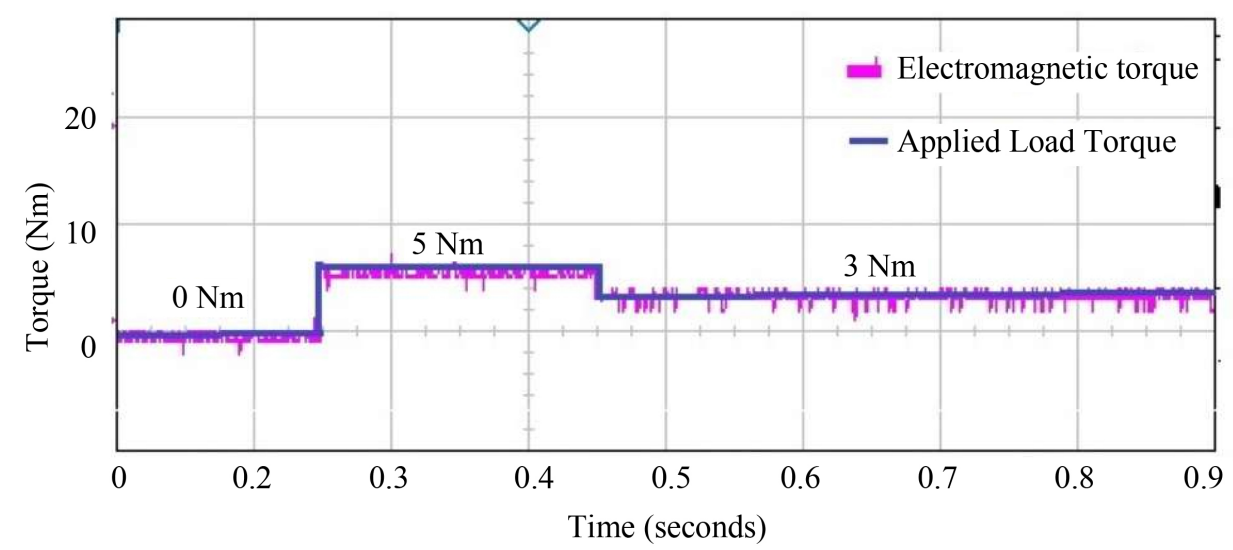

Figure 27. Torque responses for fuzzy controller when $5 \mathrm{Nm}$ is applied at $0.25 \mathrm{sec}$ and reduced to $3 \mathrm{Nm}$ at $0.45 \mathrm{sec}$.

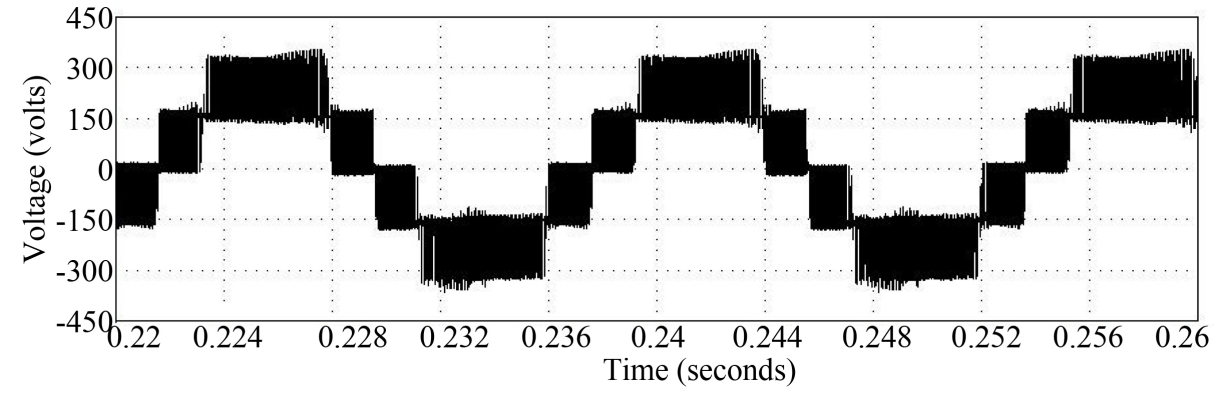

Figure 28. Line voltages of TLDCI for $\mathrm{T}_{\mathrm{L}}=3 \mathrm{Nm}$.

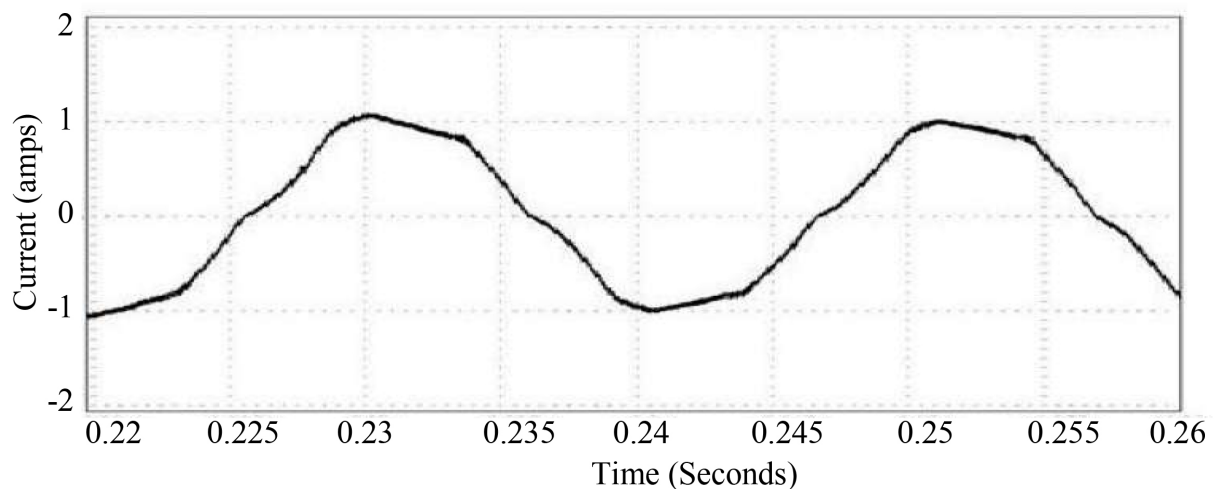

Figure 29. Line current waveform of TLDCI for $T_{L}=3 \mathrm{Nm}$.

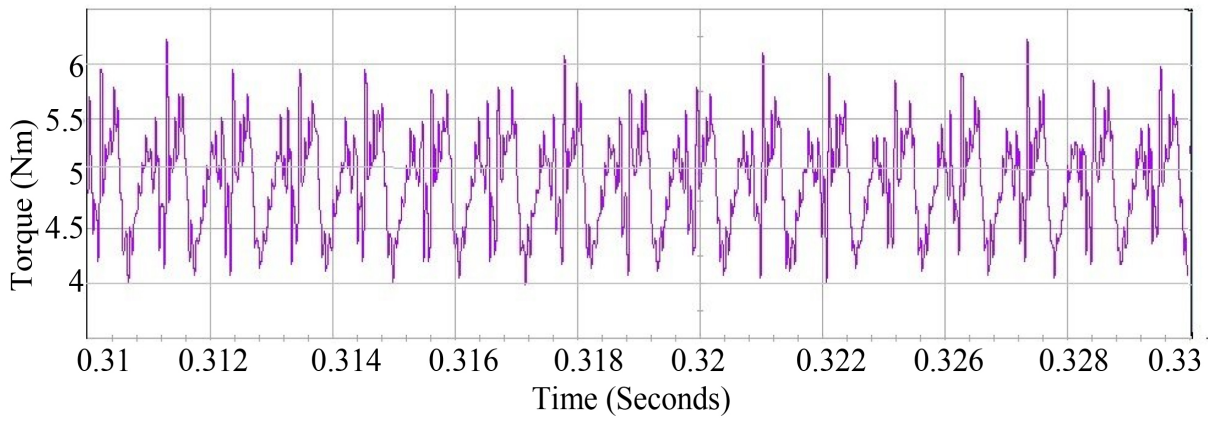

Figure 30. Torque ripple at $5 \mathrm{Nm}$ load torque for picontroller. 


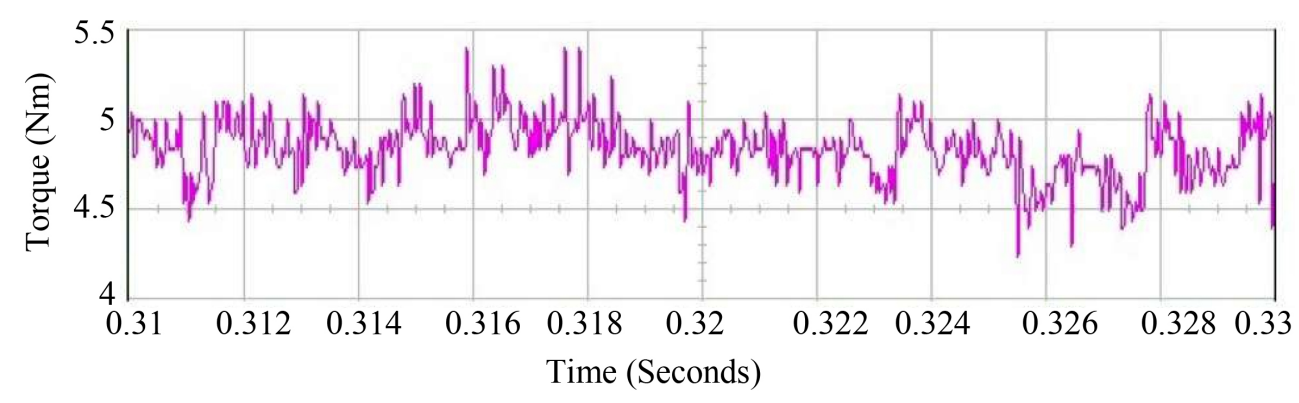

Figure 31. Torque ripple for $5 \mathrm{Nm}$ load torque for fuzzy controller.

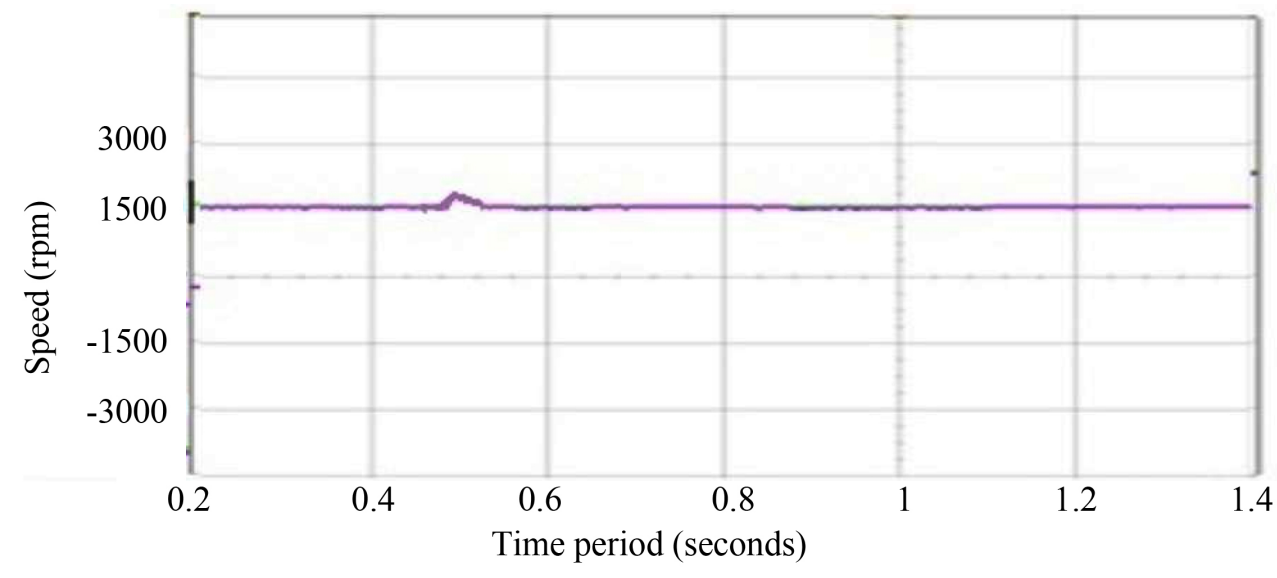

Figure 32. Speed responses when $\mathrm{T}_{\mathrm{L}}$ changed from $5 \mathrm{Nm}$ to $3 \mathrm{Nm}$ at $0.45 \mathrm{sec}$ for PI controller.

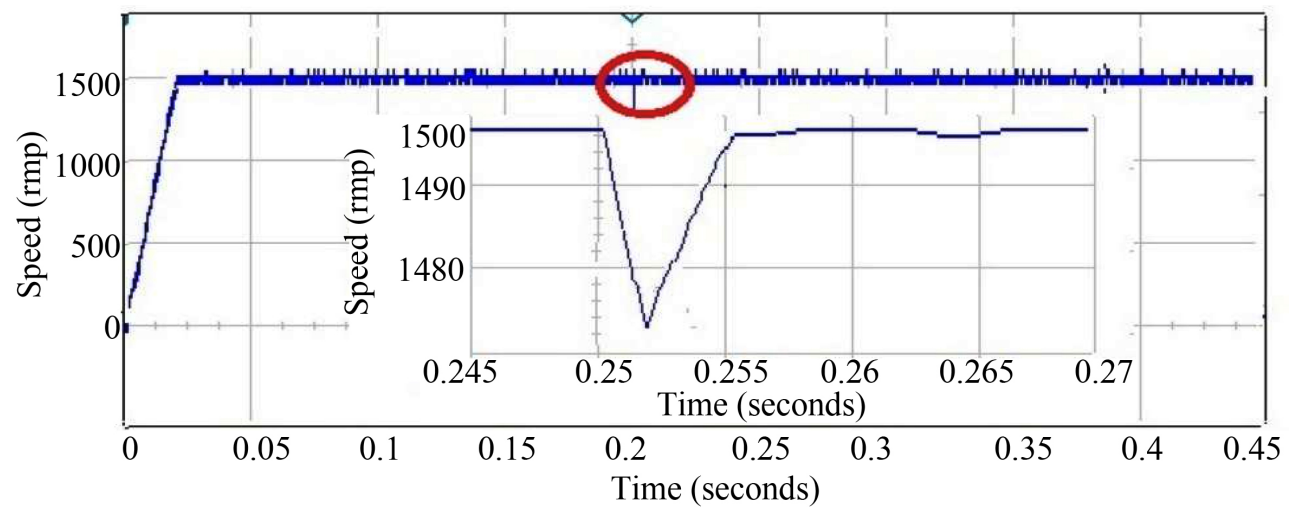

Figure 33. Speed response when $5 \mathrm{Nm}$ torque applied at 0.25 second for fuzzy controller.

Figure 37. The torque ripples vary between 15.7 and $14.3 \mathrm{Nm}$ respectively.

The simulation study is repeated on the same drive for $1000 \mathrm{rpm}$ and $1200 \mathrm{rpm}$ and the torque ripple in all the cases are measured. The PI controller is replaced by a fuzzy controller and the simulation study is carried out. Initially, the motor runs under no load, the electromagnetic torque overshoots to a value of $22 \mathrm{Nm}$ and reaches the steady state value at 0.07 seconds after the decay of transients. A load of $15 \mathrm{Nm}$ is applied at 0.25 seconds, the electromagnetic torque reaches the steady state value of $15 \mathrm{Nm}$ at $\mathrm{t}=0.257 \mathrm{~s}$ after the decay of transients and then reduced to $10 \mathrm{Nm}$ at 0.45 seconds. The corresponding torque response is shown in Figure 38 . The torque ripple corresponding to $15 \mathrm{Nm}$ load torque is shown in Figure 39.

The percentage of torque ripples calculated for different set speeds for a constant load torque of $15 \mathrm{Nm}$ with PI and fuzzy torque controller is tabulated in Table 7 for $3 \mathrm{~kW}$ induction motor. The table clearly shows that the torque ripple can be reduced by using Fuzzy Logic Controller instead of PI controller. 


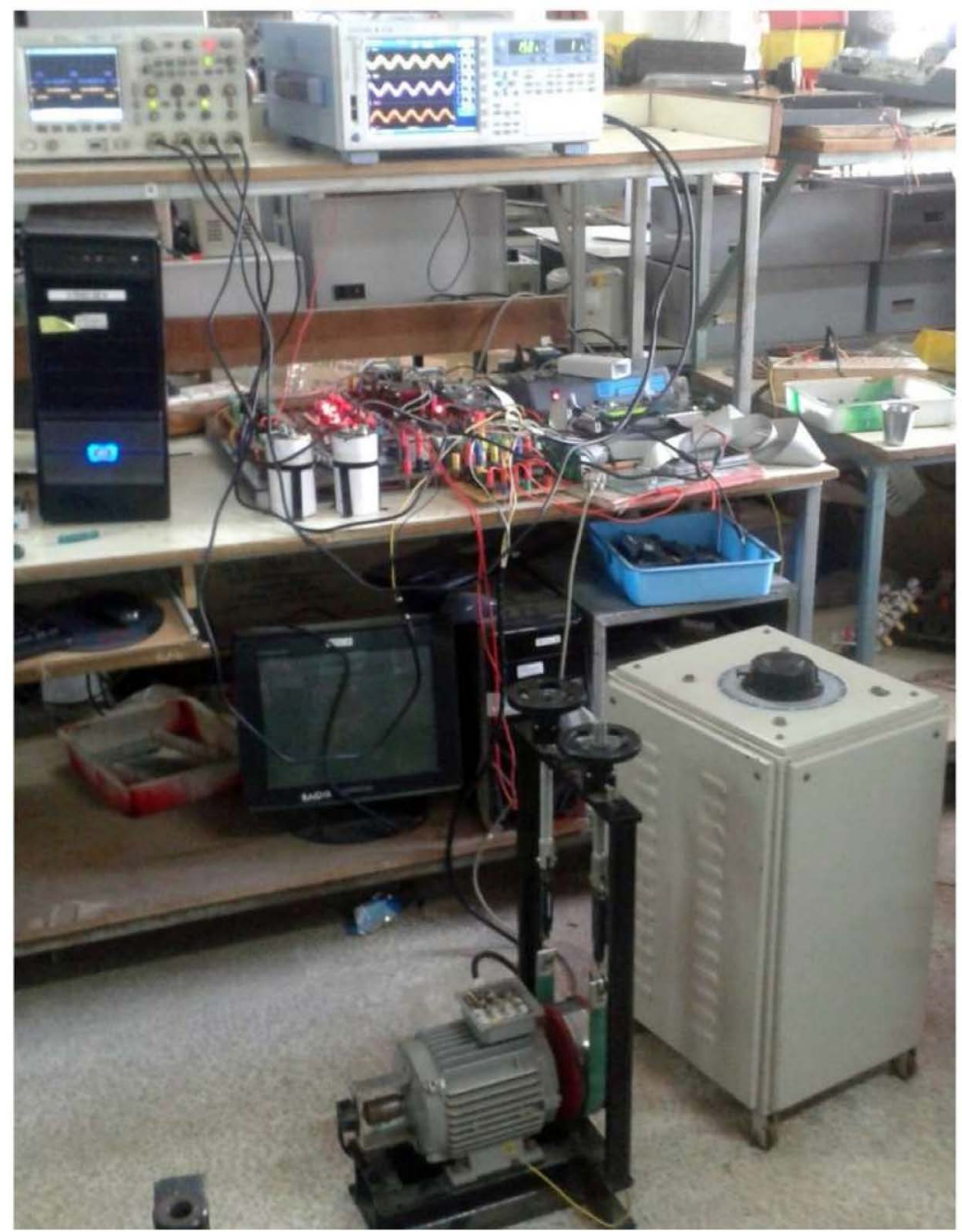

Figure 34. Experimental set with $0.75 \mathrm{~kW}$ machine.

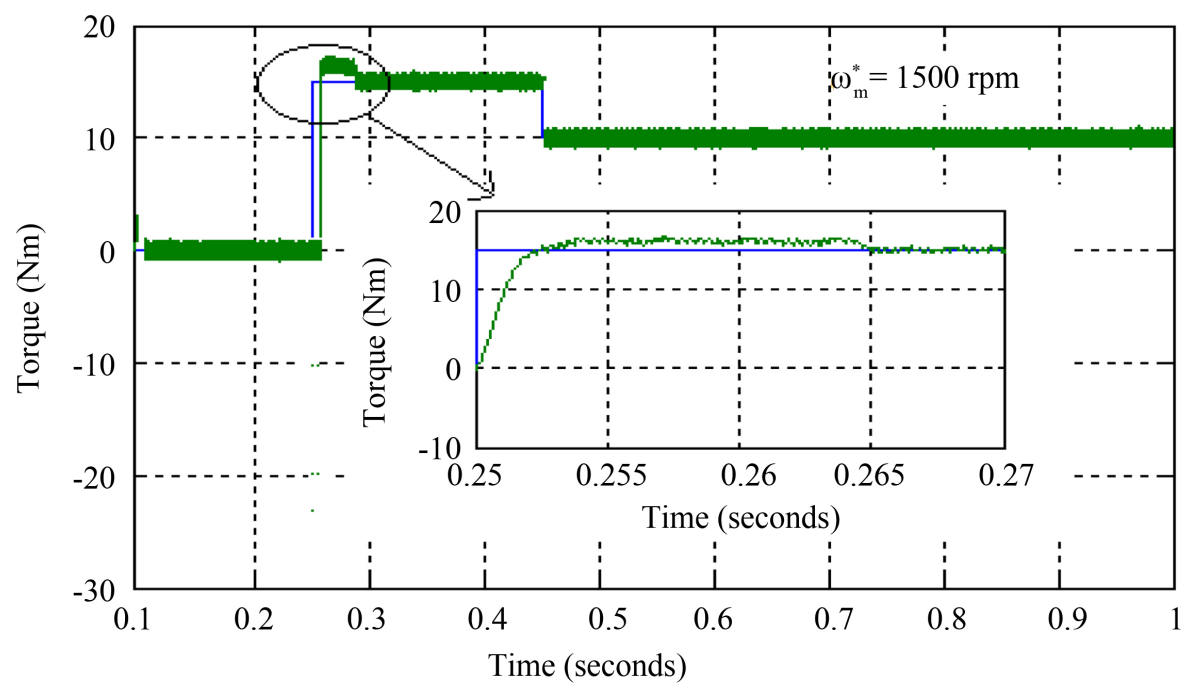

Figure 35. Electromagnetic torque response when $15 \mathrm{Nm}$ is applied at $0.25 \mathrm{sec}$ and reduced to $10 \mathrm{Nm}$ at $0.45 \mathrm{sec}$ for TLDCI fed IM with PI controller. 


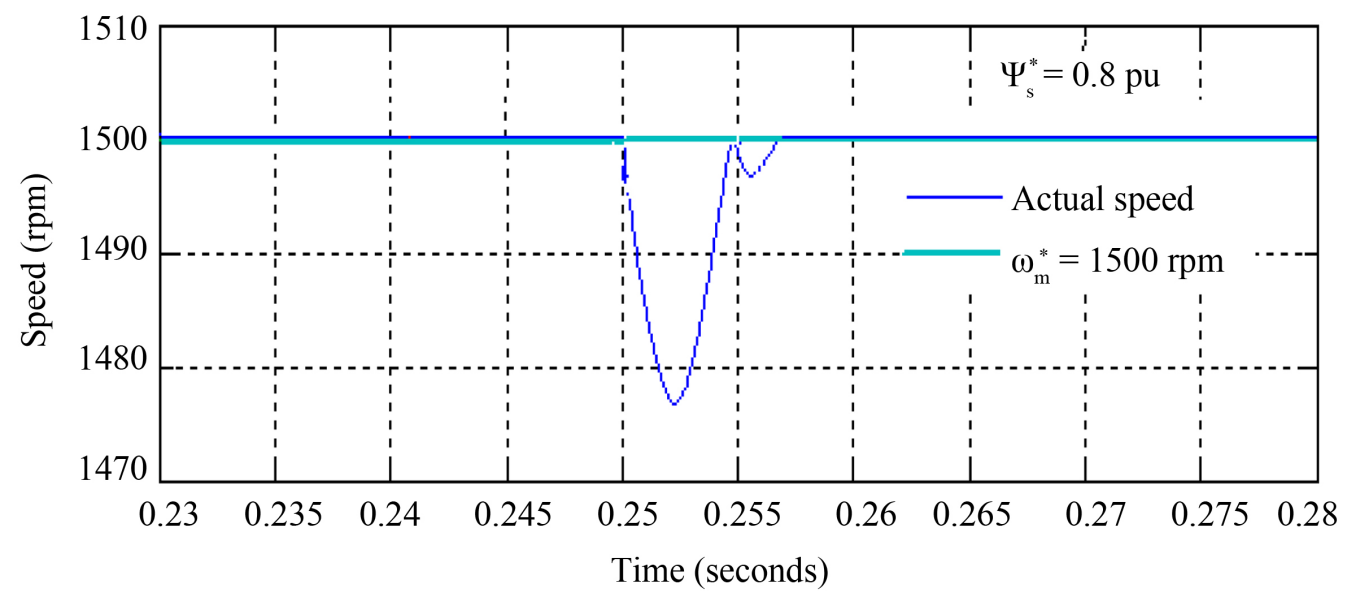

Figure 36. Speed response when $15 \mathrm{Nm}$ is applied for TLDCI fed IM with PI controller.

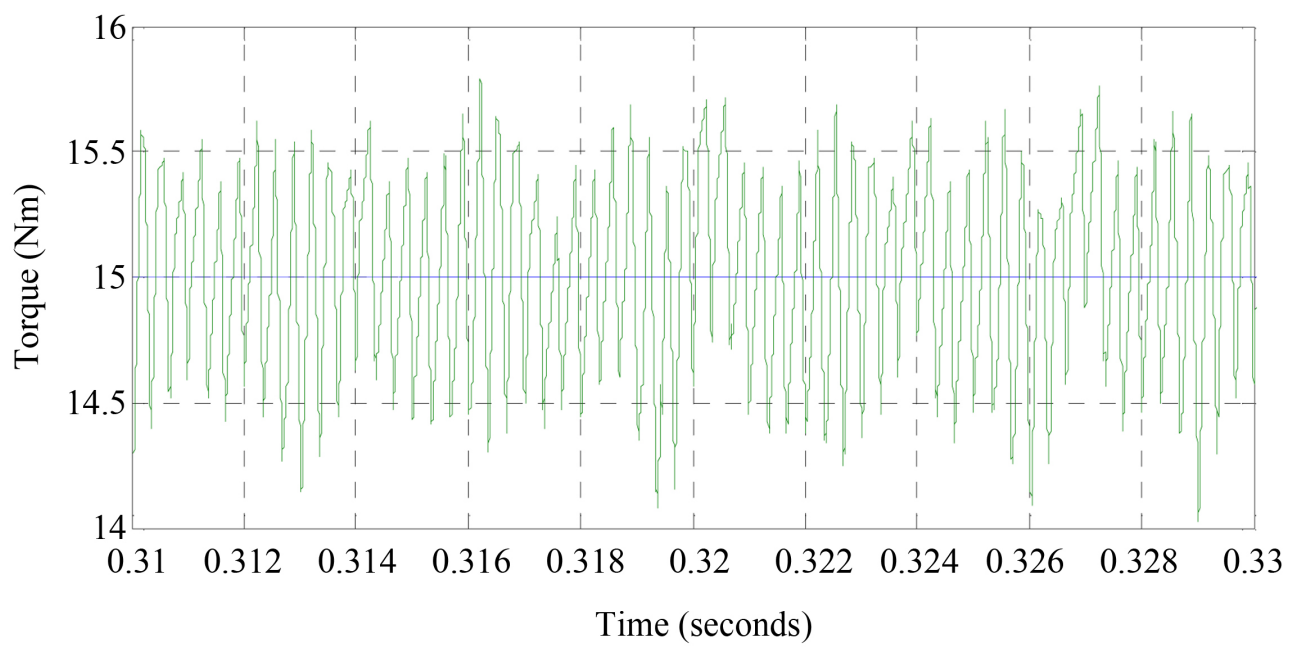

Figure 37. Torque ripple when $15 \mathrm{Nm}$ is applied for TLDCI fed IM with PI controller.

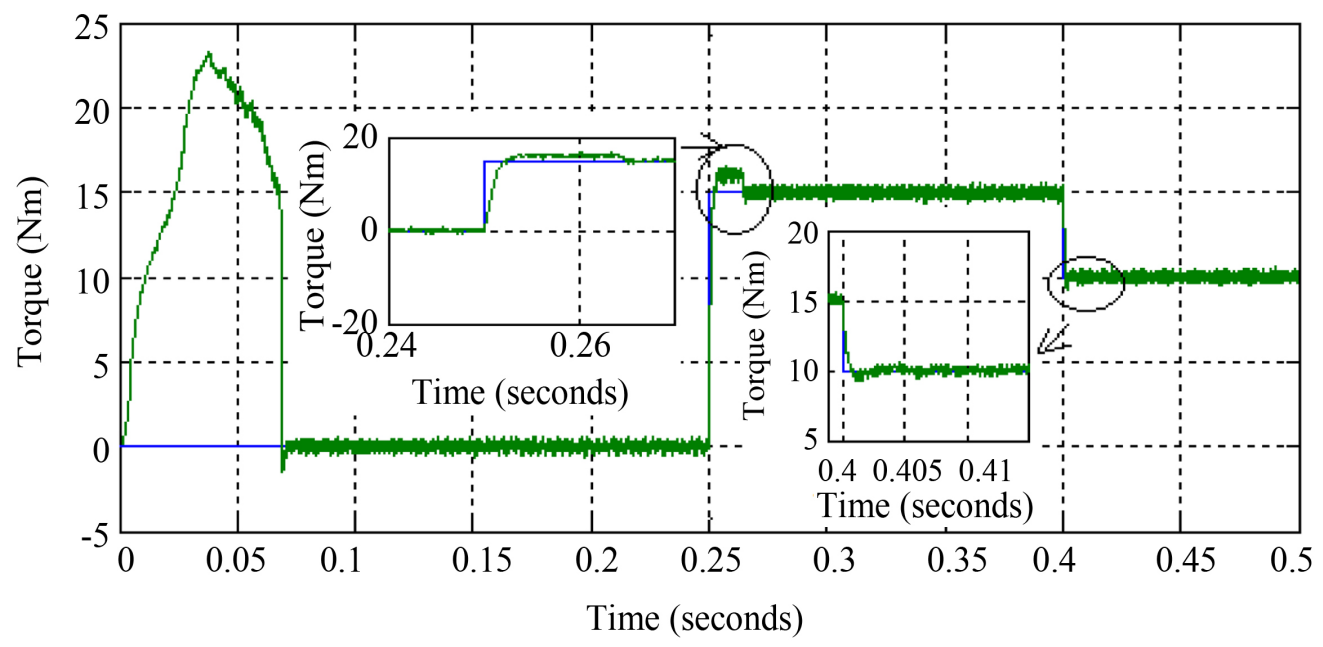

Figure 38. Electromagnetic torque response when $15 \mathrm{Nm}$ is applied at $0.25 \mathrm{sec}$ and reduced to $10 \mathrm{Nm}$ at $0.45 \mathrm{sec}$ for TLDCI fed IM with fuzzy controller. 


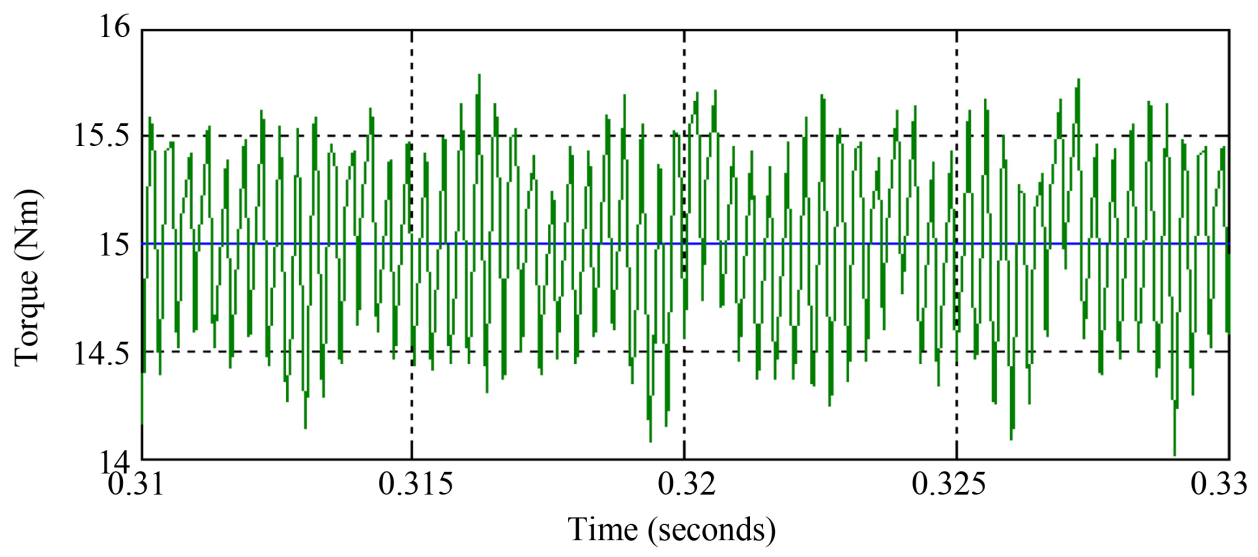

Figure 39. Torque ripple when $15 \mathrm{Nm}$ is applied for TLDCI fed IM with fuzzy controller.

Table 6. Comparison of torque ripple with PI and fuzzy controllers.

\begin{tabular}{ccccc}
\hline $\begin{array}{c}\text { Machine } \\
\text { Rating }\end{array}$ & $\begin{array}{c}\text { Speed } \\
(\mathbf{r p m})\end{array}$ & Load Torque (Nm) & \multicolumn{2}{c}{ Experimental response of Torque ripple (\%) } \\
\cline { 3 - 5 } & 1000 & 5 & PI controller & Fuzzy controller \\
\hline $0.75 \mathrm{~kW}$ & 1200 & 5 & 23.38 & 16.90 \\
& 1500 & 5 & 21.42 & 15.25 \\
\hline
\end{tabular}

Table 7. Comparison of torque ripple with PI and fuzzy controllers.

\begin{tabular}{ccccc}
\hline \multirow{2}{*}{ Machine Rating } & $\begin{array}{c}\text { Speed } \\
(\mathbf{r p m})\end{array}$ & Load Torque (Nm) & Simulated response of Torque ripple (\%) \\
\cline { 3 - 5 } & 1000 & 15 & 14.5 & Fuzzy controler \\
\hline $3.00 \mathrm{~kW}$ & 1200 & 15 & 12.80 & 12.47 \\
& 1500 & 15 & 10.07 & 11.80 \\
\hline
\end{tabular}

\section{Conclusion}

This paper investigates the influence of multilevel inverter circuits on the production of torque ripple and to identify the most suitable multilevel inverter to reduce the torque ripple when DTC scheme of induction motor is adapted. A detailed analysis of DTC is carried with H Bridge multilevel inverter and diode clampled multilevel inverter and it is concluded that DTC with Diode clamped multilevel inverter gives less ripple in comparison with DTc using H Bridge multilevel inverter. The proposed scheme is implemented and validated using a three level Diode clamped inverter circuit. The proposed scheme uses PI and fuzzy controllers for three-level space vector modulation based neutral point clamped inverter. It is observed that the torque ripples are significantly reduced and better dynamic performance is achieved with fuzzy controller in comparison with conventional PI controller. The simulation study is validated with the help of an experimental set up for $0.75 \mathrm{~kW}$ motor. The simulation analysis is repeated with a $3 \mathrm{~kW}$ motor and there also, the ripples are less with a fuzzy controller in comparison with those obtained with PI controller. Based on the study carried out, it can be concluded that torque ripples in a DTC scheme as applied to induction motor can be considerably reduced by using a multilevel inverter circuit with space vector modulation technique along with fuzzy controllers.

\section{References}

[1] Bocker, J. and Mathapati, S. (2007) State of the Art of Induction Motor Control. 2007 IEEE International Electric 
Machines \& Drives Conference, 2, 1459-1464. http://dx.doi.org/10.1109/iemdc.2007.383643

[2] Kaboli, S., Zolghadri, M.R. and Vahdati-Khajeh, E. (2007) A Fast Flux Search Controller for DTC-Based Induction Motor Drives. IEEE Transactions on Industrial Electronics, 54, 2407-2416. http://dx.doi.org/10.1109/TIE.2007.900341

[3] Saurabh, N., Pandya, A. and Chatterjee, J. (2008) Torque Ripple Minimisation in Direct Torque Control Based IM Drive, Part 1: Single-Rate Control Strategy. 2008 Power System Technology and IEEE Power India Conference, New Delhi, 12-15 October 2008, 1-8.

[4] Babu Srinivasa Kishore, Y. and Tulasi Ram Das, G. (2008) Direct Torque Control of Induction Motor Fed by Two Level Inverter Using Space Vector Pulse width Modulation. World Academy of Modeling and Simulation, 9, 136-140.

[5] Lakshmi Swarupa, M., Tulsi Ram Das, G. and Raj, P.V. (2009) Simulation Analysis of SVPWM Based 2-Level and 3-Level Inverters for Direct Torque of Induction Motor Drives. International Journal of Electronics Engineering Research, 1, 169-184.

[6] Kenn, G., Ahmed-Ali, T., Lamnabhi-Lagarrigue, F. and Arzande, A. (2009) Real-Tim Speed and Flux Adaptive Control of Induction Motors Using Unknown Time-Varying Rotor Resistance and Load Torque. IEEE Transactions on Energy Conversion, 24, 375-387. http://dx.doi.org/10.1109/TEC.2008.926042

[7] Munk-Nielsen, S. and Thøgersen, P.B. (2009) A Three-Level Space Vector Modulation Strategy for Two-Level Parallel Inverters. Institute of Energy Technology, Spring Semester Thesis, Aalborg Universitet, Denmark.

[8] Douiri, M.R., Cherkaoui, M., Nasse, T. and Essadki, A. (2011) Direct Electromagnetic Torque Control of Induction Motor Powered by High Power PWM Inverters for Two Levels or Three Levels. PIERS Proceedings, Marrakesh, 20-23 March 2011, 1456-1460.

[9] Chikhi, A., Chikhi, K. and Djarallah, M. (2011) The Direct Torque Control of Induction Motor to Basis of the Space Vector Modulation. Journal of Electrical and Control Engineering, 1, 5-10.

[10] Zhang, Y., Zhu, J., Zhao, Z., Xu, W. and Dorrell, D.G. (2012) An Improved Direct Torque Control for Three-Level Inverter-Fed Induction Motor Sensorless Drive. IEEE Transactions on Power Electronics, 27, 1502-1513. http://dx.doi.org/10.1109/TPEL.2010.2043543

[11] Singh, B., Jain, S. and Dwivedi, S. (2013) Torque Ripple Reduction Technique with Improved Flux Response for a Direct Torque Control Induction Motor Drive. IEEE Transactions on Power Electronics, 6, 326-342. http://dx.doi.org/10.1049/iet-pel.2012.0121

[12] Sekhar Chandra, O. and Chandra Sekhar, K. (2013) Simulation of Direct Torque Control of Induction Motor Drives. International Journal of Conceptions on Electrical \&Electronics Engineering, 1, 42-46.

[13] Sutikno, T., Idris, N.R., Jidin, A. and Cirstea, M.N. (2013) An Improved FPGA Implementation of Direct Torque Control for Induction Machines. IEEE Transactions on Industrial Informatics, 9, 1272-1279. http://dx.doi.org/10.1109/TII.2012.2222420

[14] Patil, U.V., Suryawanshi, H.M. and Renge, M.M. (2014) Closed-Loop Hybrid Direct Torque Control for Medium Voltage Induction Motor Drive for Performance Improvement. IEEE Transactions on Power Electronics, 7, 31-40. http://dx.doi.org/10.1049/iet-pel.2012.0509

[15] Nasir Uddin, M. and Hafeez, M. (2012) FLC-Based DTC Scheme to Improve the Dynamic Performance of an IM Drive. IEEE Transactions on Industry Applications, 48, 823-831. http://dx.doi.org/10.1109/TIA.2011.2181287

[16] Krim, S., Gdaim, S., Mtibaa, A. and Mimouni, M.F. (2015) Design and Implementation of Direct Torque Control Based on an Intelligent Technique of Induction Motor on FPGA. Journal of Electrical Engineering and Technology, 10, 30-40. http://dx.doi.org/10.5370/JEET.2015.10.4.1527

[17] Hafeez, M., Nasir Uddin, M., Abd Rahim, N. and Ping, H.W. (2014) Self-Tuned NFC and Adaptive Torque HysteresisBased DTC Scheme for IM Drive. IEEE Transactions on Industry Applications, 50, 1410-1420. http://dx.doi.org/10.1109/TIA.2013.2272031 


\section{Appendix}

Specifications of the motor used:

\begin{tabular}{ccc}
\hline Power & $0.75 \mathrm{Kw}$ & $3 \mathrm{~kW}$ \\
Voltage & $380 \mathrm{~V}$ & $380 \mathrm{~V}$ \\
Speed & $1500 \mathrm{rpm}$ & $1500 \mathrm{rpm}$ \\
Current & $1.8 \mathrm{~A}$ & $7.5 \mathrm{~A}$ \\
Stator resistance & $1.93 \Omega$ & $1.85 \Omega$ \\
Rotor resistance & $1.43 \Omega$ & $1.85 \Omega$ \\
Stator inductance & $0.7154 \mathrm{mH}$ & $170 \mathrm{mH}$ \\
Rotor inductance & $0.7154 \mathrm{mH}$ & $170 \mathrm{mH}$ \\
Mutual Inductance & $0.4154 \mathrm{mH}$ & $160 \mathrm{mH}$ \\
Moment of inertia & $0.0051 \mathrm{Kg} \cdot \mathrm{m}^{2}$ & $0.007 \mathrm{Kg} \cdot \mathrm{m}^{2}$ \\
Nominal Flux & $0.8 \mathrm{~Wb}$ & $0.8 \mathrm{~Wb}$ \\
Pole pairs & 2 & 2 \\
\hline
\end{tabular}

\section{Submit or recommend next manuscript to SCIRP and we will provide best service for you:}

Accepting pre-submission inquiries through Email, Facebook, LinkedIn, Twitter, etc.

A wide selection of journals (inclusive of 9 subjects, more than 200 journals)

Providing 24-hour high-quality service

User-friendly online submission system

Fair and swift peer-review system

Efficient typesetting and proofreading procedure

Display of the result of downloads and visits, as well as the number of cited articles

Maximum dissemination of your research work

Submit your manuscript at: http://papersubmission.scirp.org/ 